\title{
LA-5636-MS
}

UC-11

Issued: June 1974

\section{Water Supply at Los Alamos During 1973}

by

William D. Purtymun

Joseph E. Herceg 
In the interest of prompt distribution, this LAMS repart was not edited by the Technical Information siaff.

Printed in the United States of Americe. Available from National Technical Intormation Servico

U.S. Department of Commerce 5285 Pont Royal Road Springlield, Vjzginia 22151

Price: Printed Copy $\$ 1.00$ Microfiche 51.45 
WATER SUPPLY AT LOS ALAMOS DURING 1973

by

William D. Purtymun and Joseph E. Herceg

\section{ABSTRACT}

The l.os Mlanos water surply for 1973 consisted of 1566 aillion gal fros 6 wells in threc ficlds, with an additional 49 million gal from a gallery in water Canyon. Water level trends in the vell ficlds were as antieipated for current pumpage practices. Reconendations previous1y aade in tos Mamos Seicntific Laboratory reports LA5059-4S and LA-5296-NS for a new kell for the Pajarito ficld and a replaceacnt well in the Guaje field are still valid. An cxceedingly dry spring and sumacr or an outage of a high-yield well during the period of heavy pumpage could result in a shortage of supply for an indefinite persod of titic.

Gonthly puaping and production data are presentad for cach of the 16 kells and the gallery in kater Canyon for the years 1971,1972 , and 1973 .

\section{INTRODUCTION}

This report sunarizes puppage, as rell as punp and aquifer conditions, for the 16 wells in the Los Mamos, Guaje, and Pajarito well ficlds which supply aost of the water used for tunicipal and industrial purposes in los Mamos. A gallery in hater Canyon which makes an apprecialile contribution to the los Manos water supply is also discussed briefly. The appendix contains basic pumping and production statistics for supply wells oll a nonthly basis for 1971, 1972, and i973.

Water is pumped from the wells (Fig. 1) through transaission lines, and lifted by booster puaps inzo reservoirs for storage and distribution. Nater from the gallery flows by aravity through a microfilter station and is puaped into one of the system reserwoirs for distribution.

\section{MOIICE}

thus erfind nas propared us an account of wotk

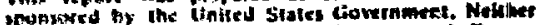

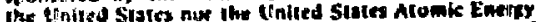
com

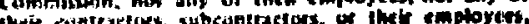

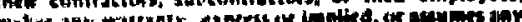

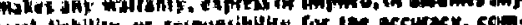

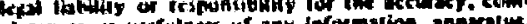

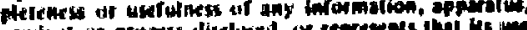

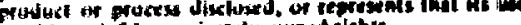

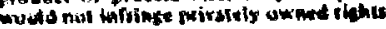

The Itifities and Engineering (U/E) Division of the zia Company, the USAEC support contractor at Los Alamos, maintains and operates the water-supply system and pro$v$ ides production and water level data to the Los Manos Scientific Laboratory Environmental Studies Group, $\sharp-8$, for interpretation and cvaluation. The purpose of the joint effort is to ensure reliable and continuing historical records, provide guidance for management of water resources and facilitics, and provide for long-range planning for the water-supply sysiem. One summary report ${ }^{1}$ and tho previous annual reports ${ }^{2,3}$ have been issued as a result of these studies.

Pump operating time and pumpage are taken from monthly operating reports. Month$1 y$ average nonpuming and pumping water levcls are computed from air-line recorders 


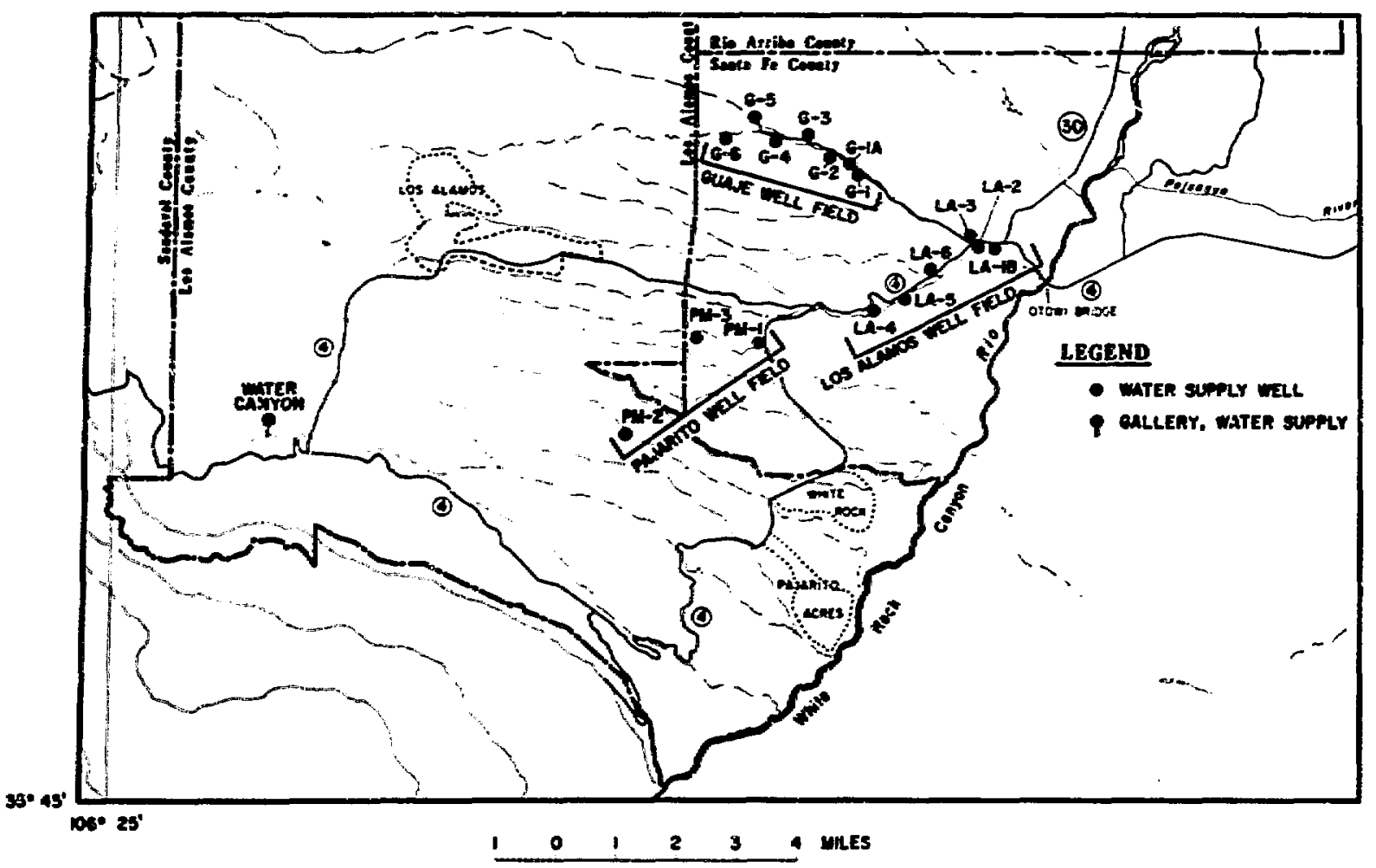

Fig. 1. Loeation of well ficlds, supply velze, and gallery vater supply.

operated on each well. These data are input information for a computer progran that calculates pumping rates, drawdown (difference between monthly average nonpumping and pumping water levels), specific capacity (pump rate per unit drawdown), and other statistics of interest.

Hydrographs have been prepared for one observation well and 16 supply wells. They show monthly average nonpumping and pumping water levels (a measure of well conditions). and the monthly and yearly pumpage.

\section{WELL-FIELD CHARACTERISTICS \\ Production during 1973 was from six} wells in the los Alamos field, seven wells in the Guaje field and three wells in the Pajarito field (Fig. 1). Pumpage from the three fields increased by 56 million gal, from $1510 \mathrm{mllli}$ ion $\mathrm{gal}$ in 1972 to $1566 \mathrm{mil}$ lion gal in 1973 (Table 1). The total pumpage from the three well fields since 1947 has been 26748 million gal. The annual production for the individual wells is shown in Table II, and monthly production data for 1971, 1972, and 1973 arc given in the Appendix.

The average yearly pumping rate for the three well fields decreased $130 \mathrm{gpm}$ from $8837 \mathrm{gpm}$ in 1972 to $8707 \mathrm{gpm}$ in 1973 (Table III). The maximum average pumping rate was $9139 \mathrm{gpm}$ in 1968. The average yearly pusping rate indicates pumping conditions of wells in the three fields and should not be construed to mean that water can be delivered continuously at this rate. 
TOTAL PUASPAGE BY FIELD BY YEAR

IN MILLIONS OF GALLONS

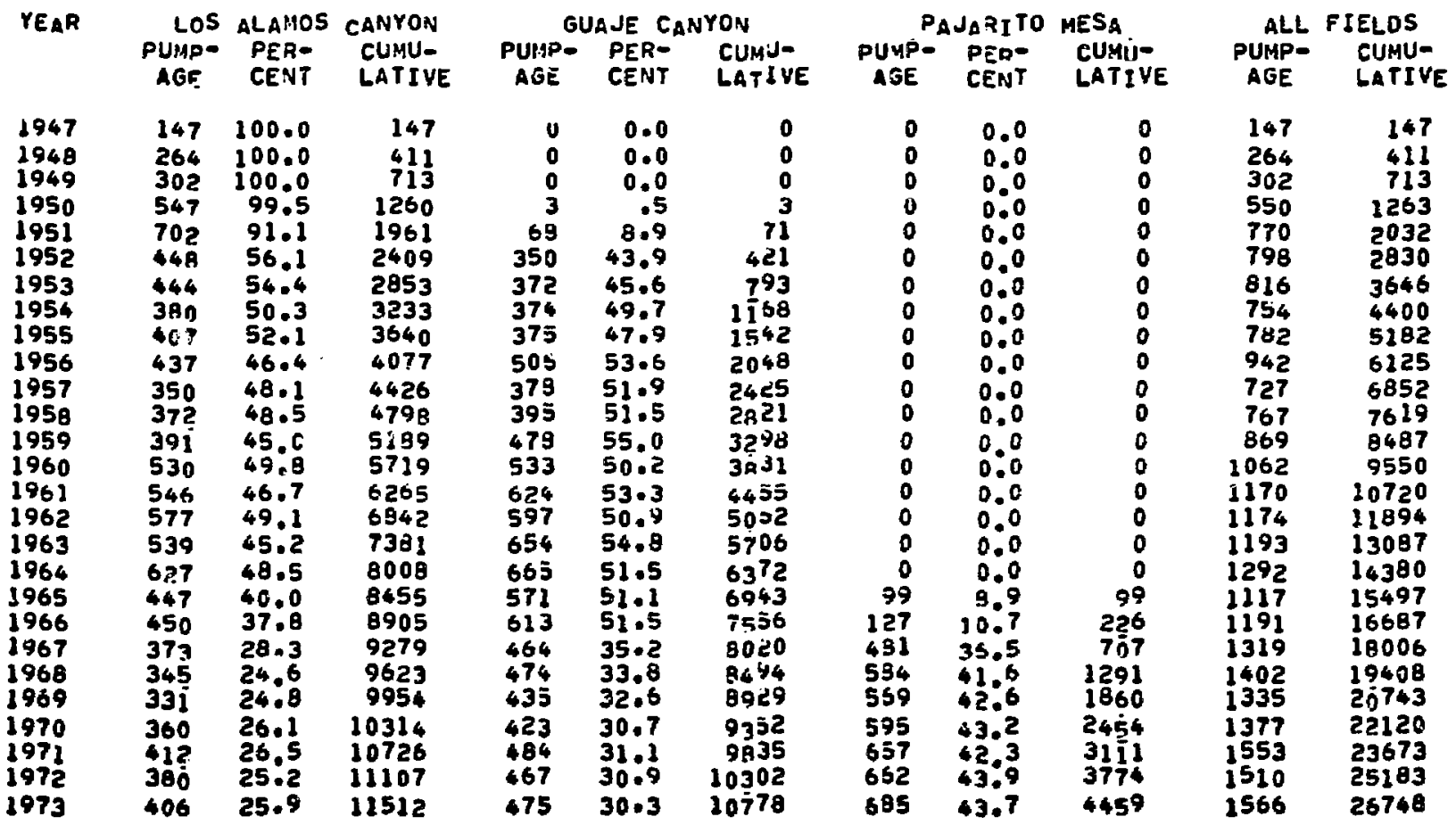

The heaviest demands for water in 1973 occurred in June, July, and August while January, February, March, November, and December were months of least pumpage. Water for irrigation is responsible for the increased demands for water during the late spring and summer. is a result, the highest water levels in the well fields occur in the winter and carly spring when pumpage is the least, and lowest levels occur during the summer when pumpage is the greatest.

rables IV and $V$ present percents of total pumpage and of ficld pumpage, respectively, for all wells by year.

A. Los Mlamos liell field

Pumpage from the Los Mamos well field increased 26 million gal from 380 million gal in 1972 to 406 million gal in 1973. The six wells produced $25.9 \%$ of the total pumpage.

Well LA-1 ceased operations as a supply well in 1956 due to a sand problem and is now used as an observation well to monitor water level trends in the lower part of the Los Alamos well field. The well was replaced by well LA-1B which is located about $150 \mathrm{ft}$ northeast of $\mathrm{LA}-1$. Water-level trends in well LA-1 (Fig. 2) therefore main1y reflect pumpage from nearby LA-1B.

Pumpage from well LA-1B was 12 million gal greater and water levels were slightly lower in 1973 than in 1972 (Fig. 3 ).

Pumpage from well LA-2 was 8 million gal greater and water levels were slightly lower in 1973 than in 1972 (Fig. 4). 


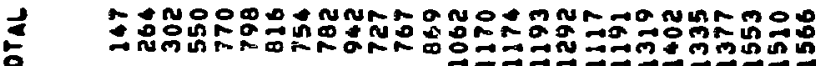

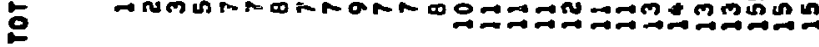

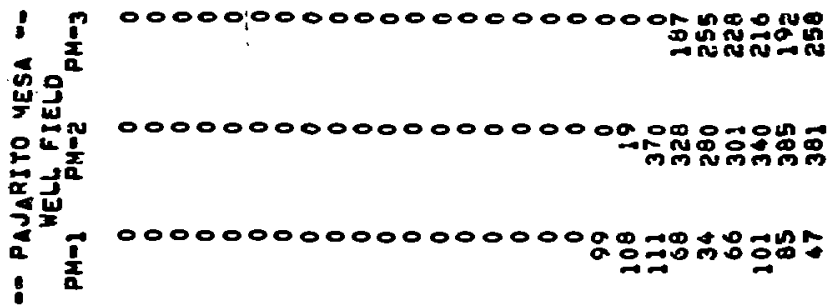

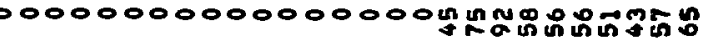

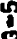

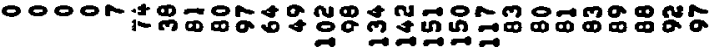

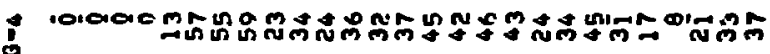

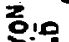

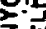

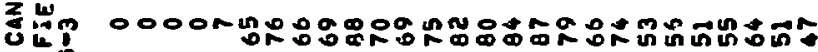
山ैं

空雪

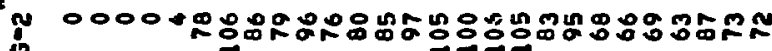

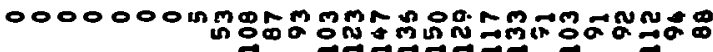

:

!

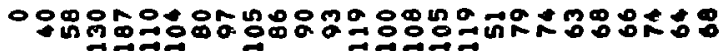

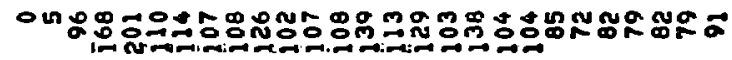

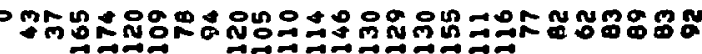

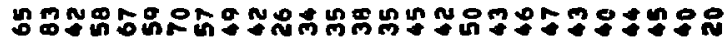

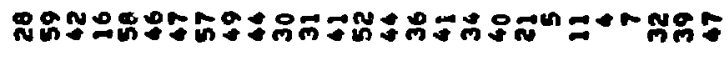
$\stackrel{9}{0}$

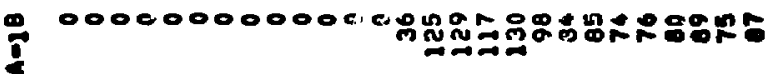

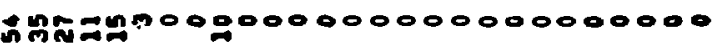
I

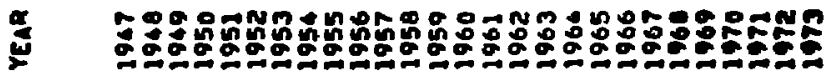




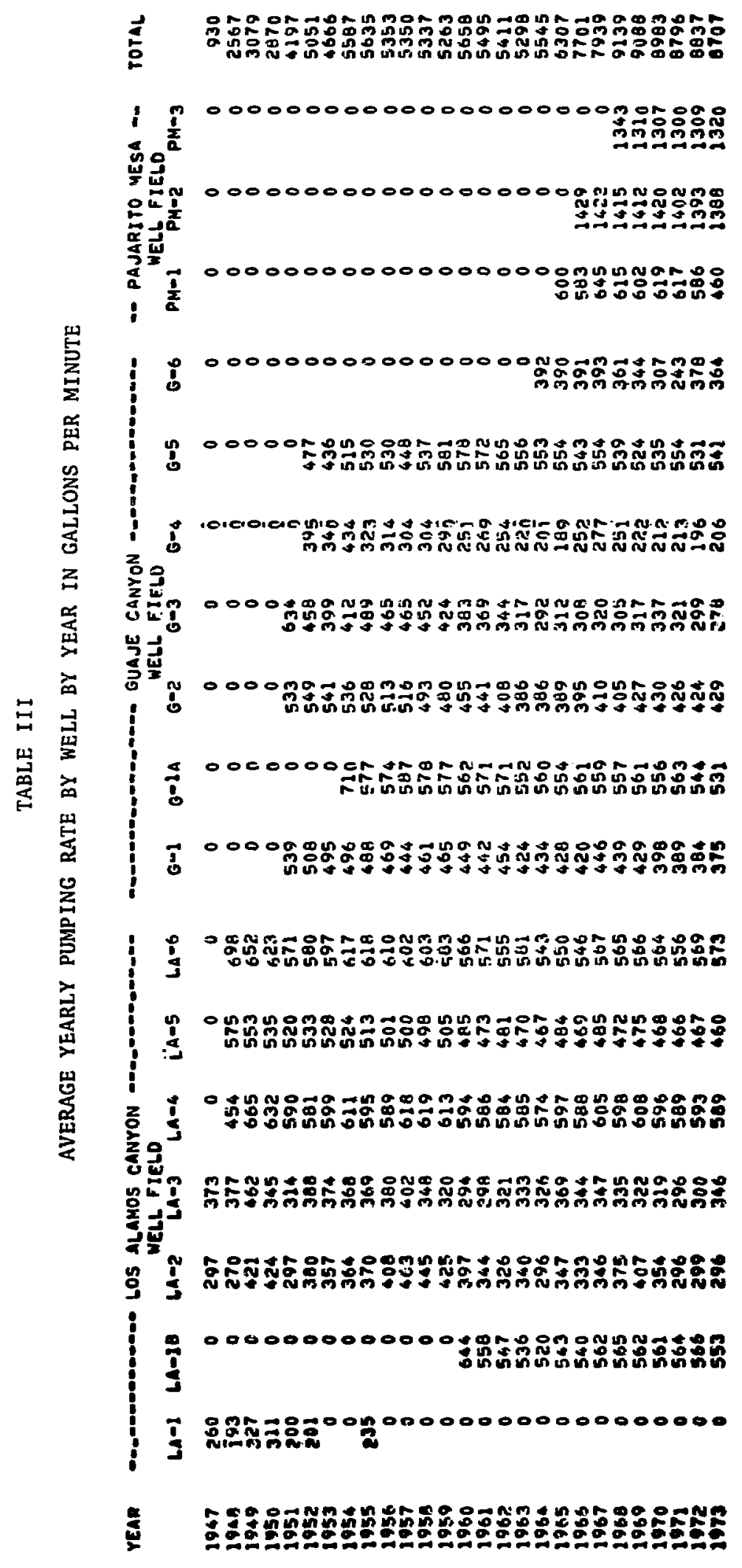


1 1 000000000000000000000 - nam 萑 舫

In $000000000000000000000000 \mathrm{~nm}$

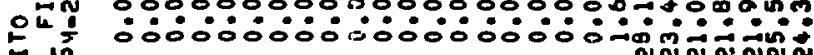

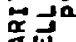

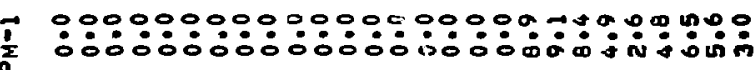
:

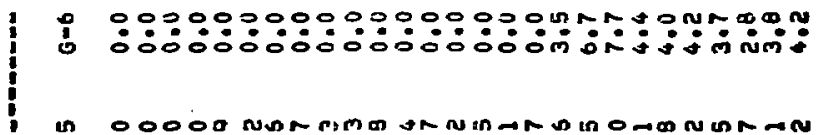
I

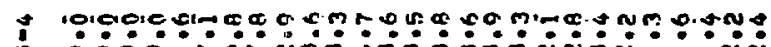
20

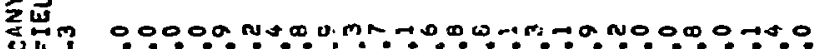
岁

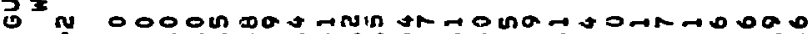

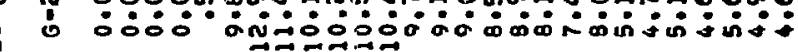

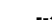

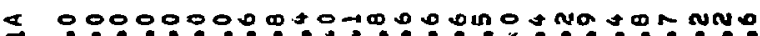
$\vec{B}: 000000$ inn

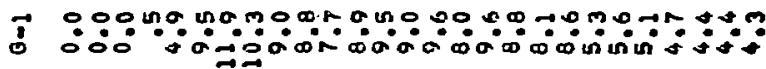

: O

窟

n ond

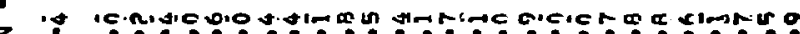
z $\sum^{3}$

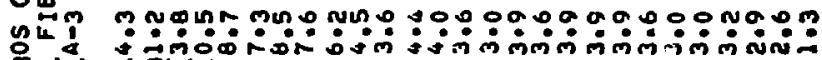

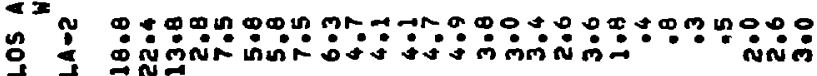

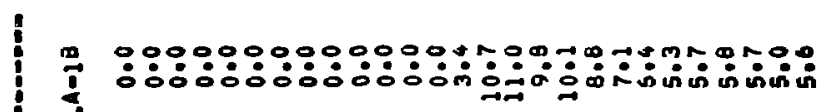
I

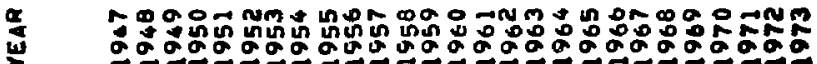


( ถึ응 崖越

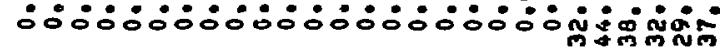

in 000000000000000000000 nNonNo

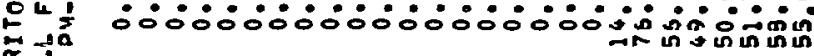
$\sum_{1} \frac{11}{3}$

1 :

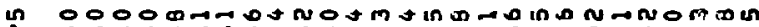

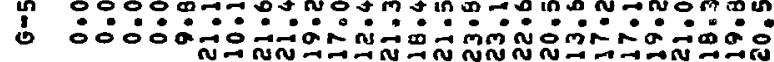
: 옹

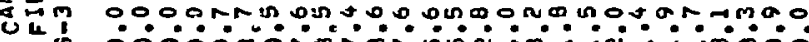
ư

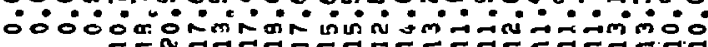
过

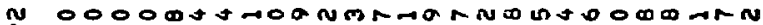

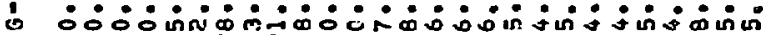

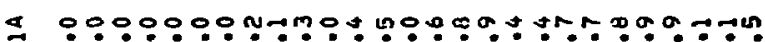

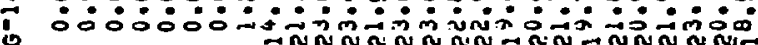

I $0000 m 4=0 \alpha n \propto N m 00$ m

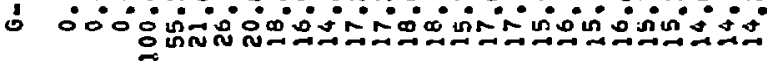

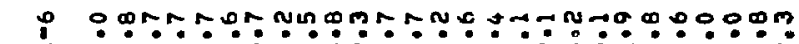

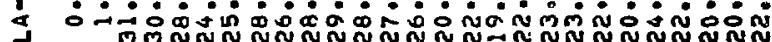

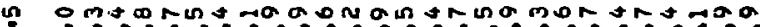

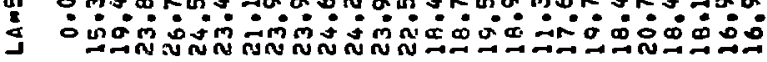

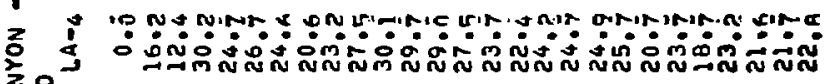
m no ungr $\rightarrow 0$ un on

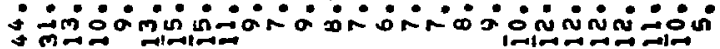

\% $9 \div 0$ \% I I

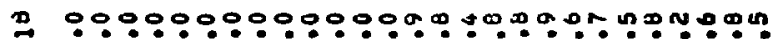

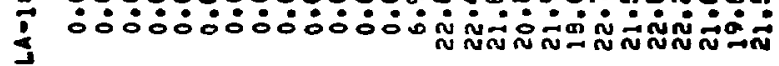

I

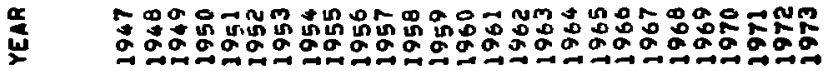




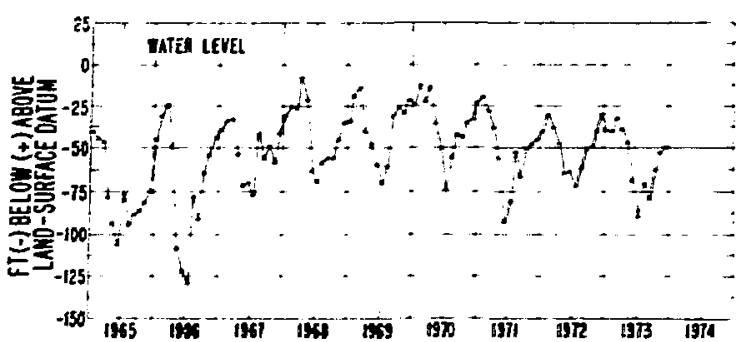

Fig. 2. Honthly average daily high water level, Ios Alomos Conyon wel2, LA-1.

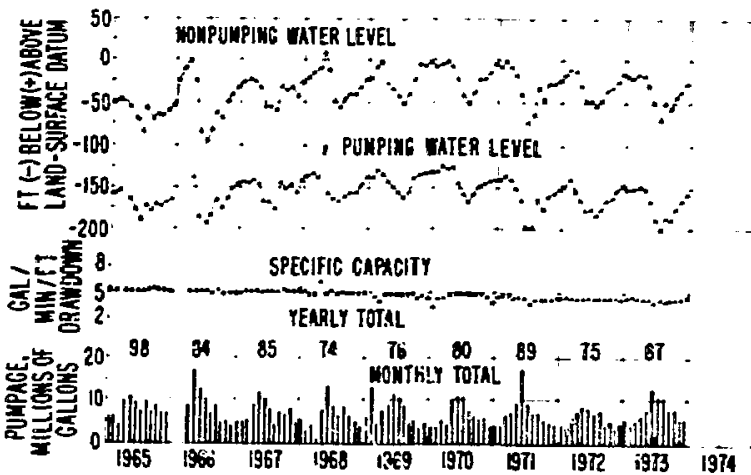

Fig. 3. Honthly average nonpwrping and pisping water level, monthly average specific capac$i t u$, and monthly and yearly purpage, Los Alomos Canyon supply well LA-1B.

Pumpage from well LA-3 decreased 20 million gal and water levels were slightly higher in 1973 than in 1972 (Fig. 5). The we 11 was taken out of service on May 16 because of a possible problem with the chemical quality of the water. It was pumped on1y for testing during the subsequent sixmonth period. After the quality of the water was found to be acceptable, the well was put back into service on November 20 .

Pumpage from well LA-4 was 9 million gal greater and water levels were slightly lower in 1973 than in 1972 (Fig. 6).

Pumpage from wel1 LA-5 was 4 million gal greater and water levels were slightly lower in 1973 than in 1972 (Fig. 7). The pump was taken out of service in December due to a mechanical problem.

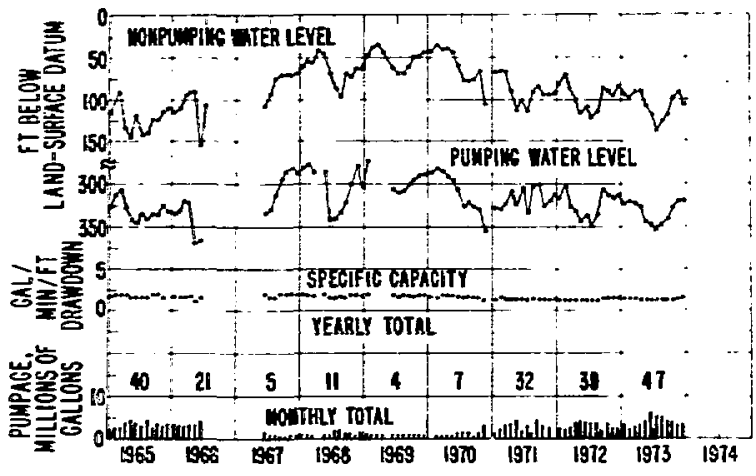

Fig. 4. Konthly average nonptomping and proming water level, monthly werage specific capacity, and monthly and yearly prompage, Los Alamos Coriton supply well LA-2.

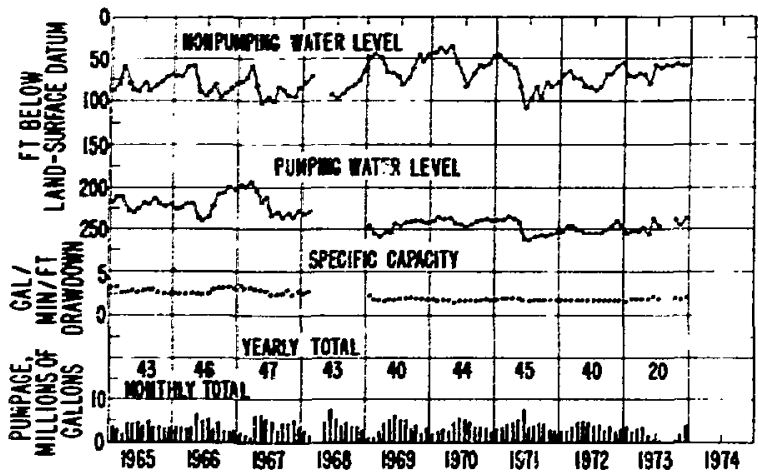

Fig. 5. Honthly average nonpumping and pumping water Zevel, monthly average specific capacity, and monthly and yeorly prompage, tos Alamos Conyon supply well LA-3.

Pumpage from well LA- 6 was 12 million gal greater in 1973 than in 1972 and no significant water level changes occurred (Fig. 8).

Due to increased production in the past few years, there has been a slight water level decline in the Los Alamos well field. The decline is as anticipated under the present amount of pumpage. The year1y pumping rate from the six wells increased 23 gpm from $2794 \mathrm{gpm}$ in 1972 to $2817 \mathrm{gpm}$ in 1973. There was no significant change in specific capacities in the six wells. 


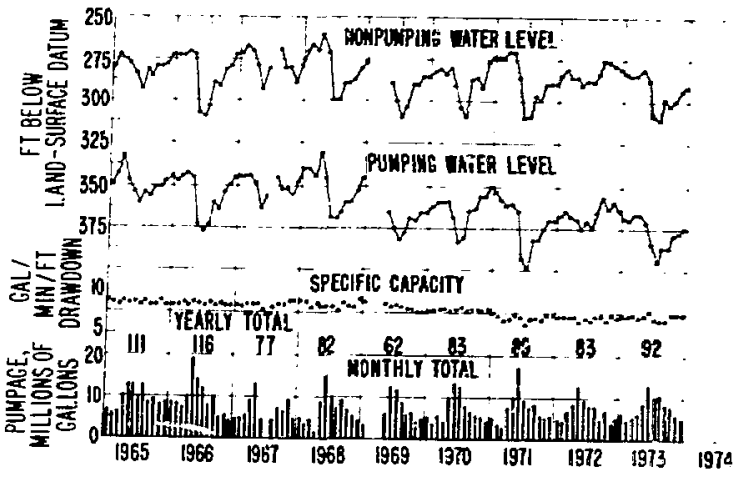

Fig. 6. Monthly average nonpumping and pumping water level, monthly average specific capacity, and morthly and yeorly pumpage, tos Alamos Canyon supply well LA-4.

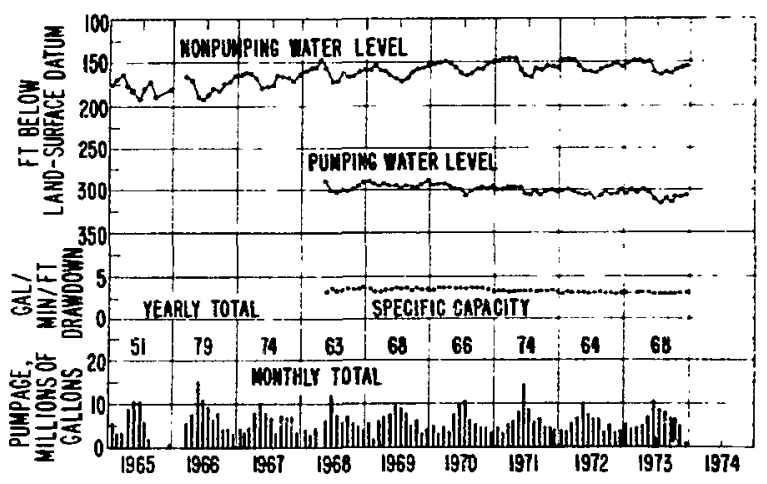

Fig. 7. Monthly average nonpumping and pumping water levels, monthly average specific capacitys and monthly and yearly pumpage, Los Alomos Canyon supply well LA-5.

\section{B. Guaje Well Field}

Pumpage from the Guaje well field increased 8 million gal from 467 million gal in 1972 to $475 \mathrm{million} g a 1$ in 1973. The seven wells in the field produced $30.3 \%$ of the total pumpage (Table I).

Pumpage from well G-1 was one million gal greater and water levels were slightly lower in 1973 than in 1972 (Fig. 9).

Pumpage from well G-1A decreased $6 \mathrm{mil}$ lion gal and no significant water level changes occurred from 1972 to 1973 (Fig.

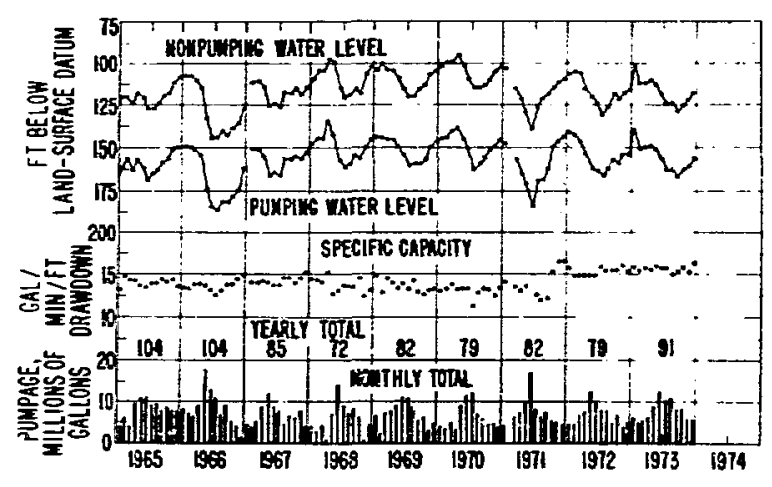

Fig. 8. Honthly average nompwomping and pumping water level, monthly average specific capacity, and monthly and yearly pumpage, Los Alamos Conyon supplz well LA-6.

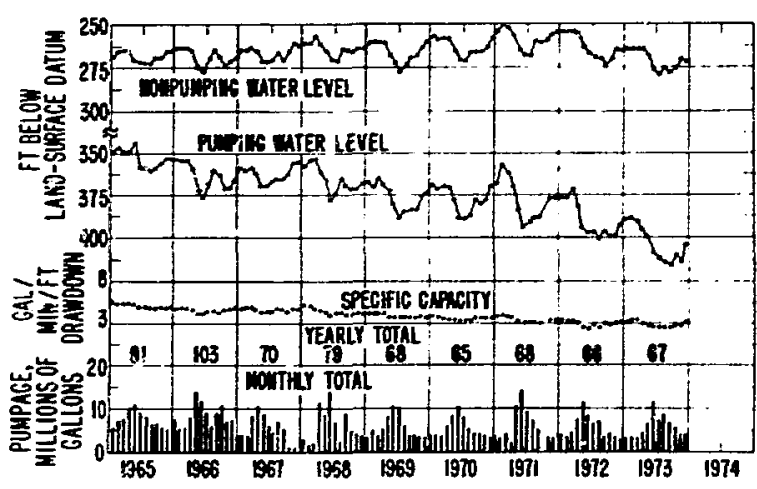

Fig. 9. Monthly average nonpwnping and pwmping water level, monthly average specific capacity, and monthly and yearly pumpage, Guije Canyon supply well $G-1$.

10). The pumping rate declined about 40 gpm from January through November, while specific capacities have declined for the past few years. The we 11 was taken out of service on November 22 to have the pump rebuilt and the sand cleared out of the well. The pump has been in the well since 1954 .

Pumpage from we11 G-2 decreased one million gal and water levels showed no significant change from 1972 to 1973 (Fig. 11). 


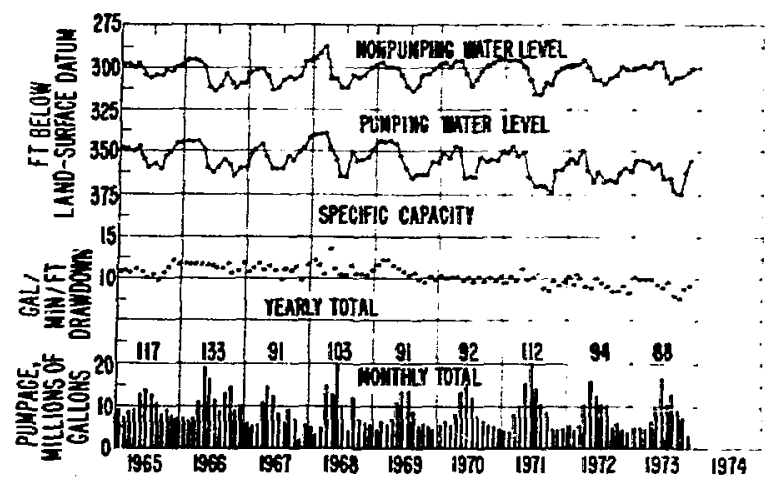

Fig. 10. Monthly average nonpromping and pumping water level, monthly coverage specific capacity, and monthly and yearly pumpage, Guaje Canyon supply well G-1A.

Pumpage from well G-3 decreased 4 million gal and water levels showed no significant change from 1972 to 1975 (Fig. 12).

Pumpage from well G-4 was 4 million gal greater and water levels were slightly lower in 1973 than in 1972 (Fig. 13).

Pumpage from well G-5 was 5 million gal greater and water levels showed no significant changes from 1972 to 1973 (Fig. 14).

Pumpage from well G-6 was 8 million gal greater and water levels were slightly lower in 1973 than in 1972 (Fig. 15).

In general the water levels follow the anticipated trends under the present amount of pumpage. Yearly average pumping rate declined $32 \mathrm{gpm}$ from $2756 \mathrm{gpm}$ in 1972 to 2724 $\mathrm{gpm}$ in 1973. Specific capacities of the wells are static or are showing slight declines.

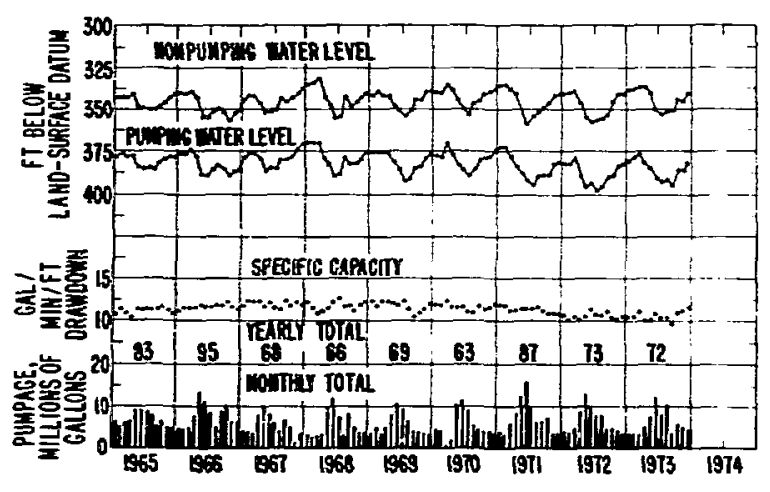

Fig. 11. Honthly average nonpwoming and pumping water level, monthly average specific capacity, and monthly and yearly prompage, Guaje Canyon supply well G-2.

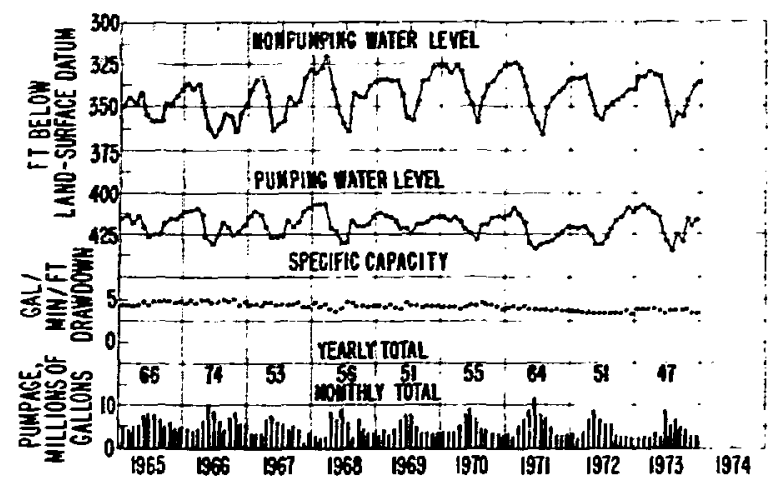

Fig. 12. Konthly average nonpumping and pumping water level, monthly average specific capacity, and monthly and yearly prompage, Guaje Canyon supply well $G-3$.

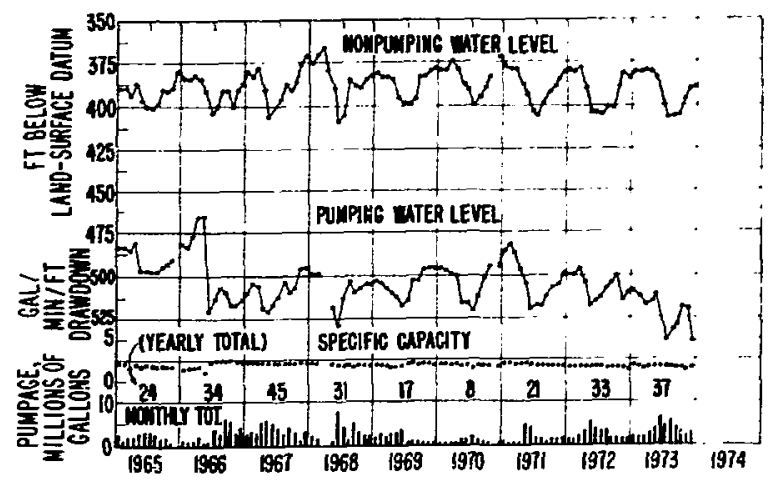

Fig. 13. Monthly average nonpumping and pumping water level, monthly average specific capac$i t y$, and monthly and yeorly pumpage, Guaje Canyon supply well G-4. 


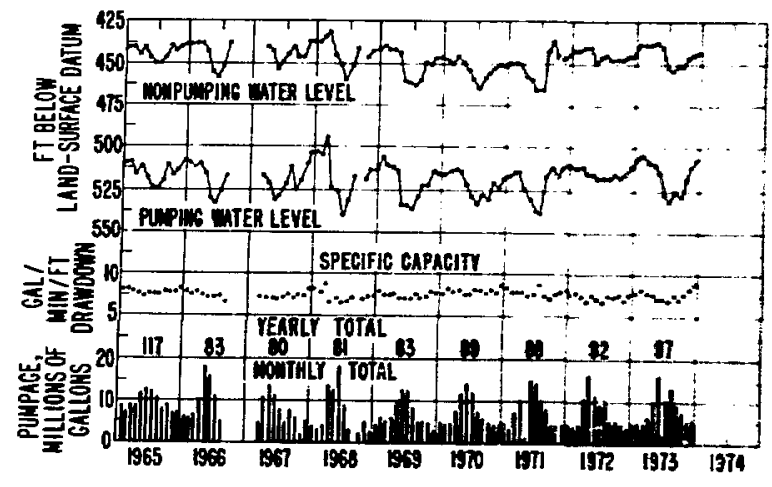

Fig. 14. Monthly average nonpumping and purpirg water level, monthly average specific capacity, and monthly and yearly purpage, Guaje Canyon supply well G-5.

\section{Pajarito Well Field}

Pumpage from the Pajarito well field increased $23 \mathrm{million}$ gal from 662 million gal in 1972 to 685 million gal in 1973. The three wells produced $43.7 \%$ of the total pumpage (Table I).

Pumpage from well PM-1 decreased 38 million gal, and as a result water levels were slightly higher in 1973 than in 1972 (Fig. 16). The pumping rate declined fron about $580 \mathrm{gpm}$ in January to about $360 \mathrm{gpm}$ in October. The pump was pulled and replaced and about $300 \mathrm{ft}$ of sand was cleaned out of the bottom of the well. The well was out of service from October 17 to the end of December.

Pumpage from well $\mathrm{PM}-2$ decreased $4 \mathrm{mil}$ lion gal and water levels were slightly lower in 1972 than in 1973 (Fig. 17).

Pumpage from well PM- 3 increased 66 million gal and water levels were lower in 1973 than in 1972 (Fig. 18).

The water level trends in well PM-1 show recovery in the past few years due to a decline in pumping rate and some additional development of the well. Water levels in wells PM-2 and PM-3 show slight declines for the past few years. Water levels are following their anticipated trends under the present amount of pumpage. Average

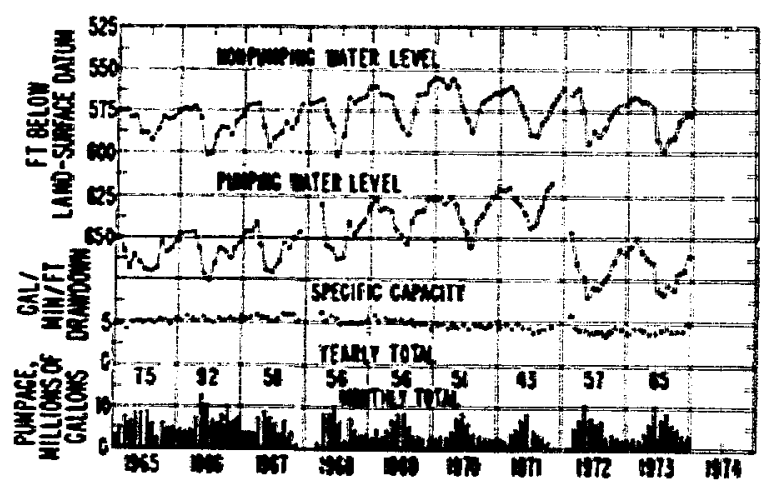

Fig. 15. Hontihly average nongriping and paming

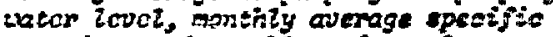
capacity, and morthity and yearity purpage. Gisjc Canyon ougly wall G-6.

annual pumping rate declined $120 \mathrm{gpm}$ from $3288 \mathrm{gpm}$ in 1972 to $3268 \mathrm{gpm}$ in 1973. The largest decline in pumping rate occurred in P!l-1 during the tire prior to pump Eailure. The specific capacitics show no significant changes from 1972.

\section{WATER CANYON WATER SUPPLY}

Production from the gallery in water Canyon increased about 9 million gal from about 40 nillion gal in 1972 to about 49 million gal in 1973. The gallery is an excelient source of water, producing as wuch water from gravity flok as is pumped from some of the weaker wells (LA-2, LA-3, and G-4). Production data for 1971, 1972, and 1975 are shown in Table $v i$.

IV. SUMMARY

Pumpage has generally increased since the first well went into production in 1947, but the increase has been erratic in the past seven years (Table VII).

Pumpage increased 56 aillion gal or 172 acre-ft from 1972 to 1973. Requirements vary widely depending on precipitation, e.g., pumpage during a liet spring and summer will be reduced, whereas a dry spring and summer will result in a considerable increase in pumpage. 


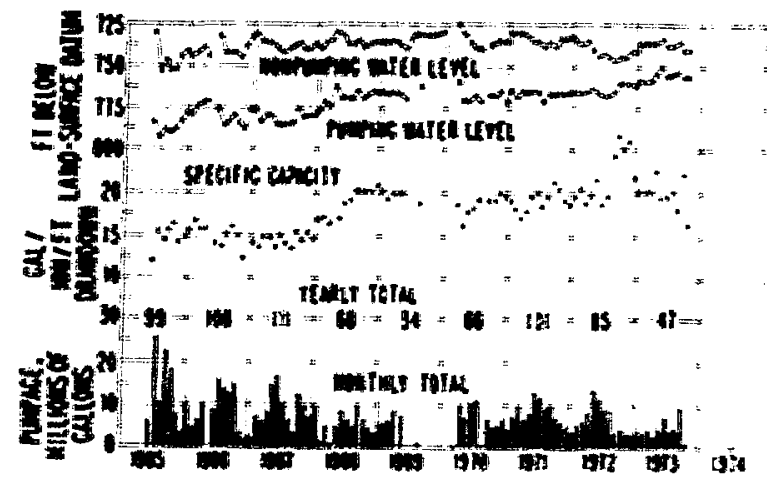

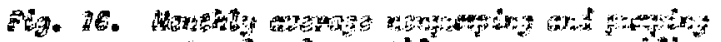

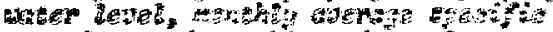

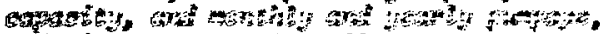

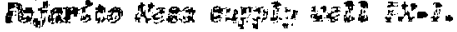

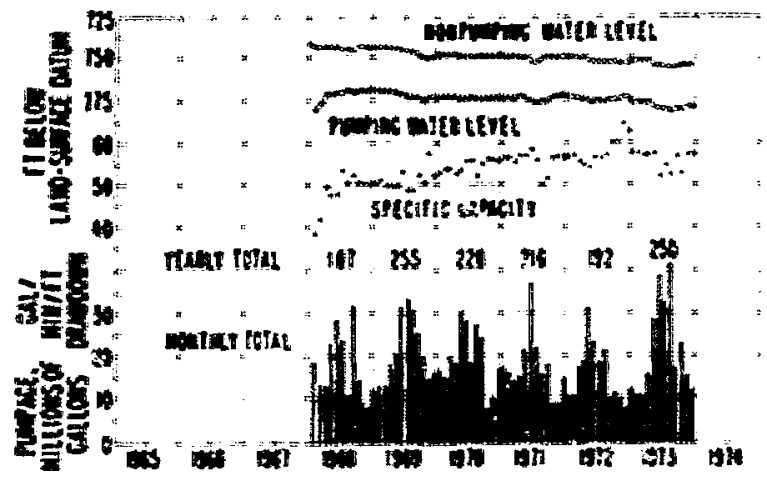

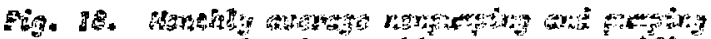

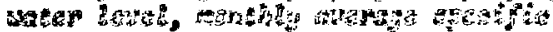

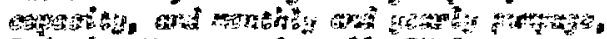

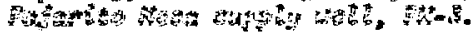

Expansion of taboratory faetitics and population snd housting increases in the councy vill undoubzediy restut in demands for a greater increase in produceion. The State Ensincer has escablished underground water rights for the three well fields at S325 acre-fe/yr.

Well fleld operacions during 1925 were satisfactory. Nater-level erents in the Los Manos, Guje and Pajarito well fields fell within the range expected fron crends establishci during the past ejght years. Two wells, PW-1 and $6-1 \mathrm{~A}$, were down for re-

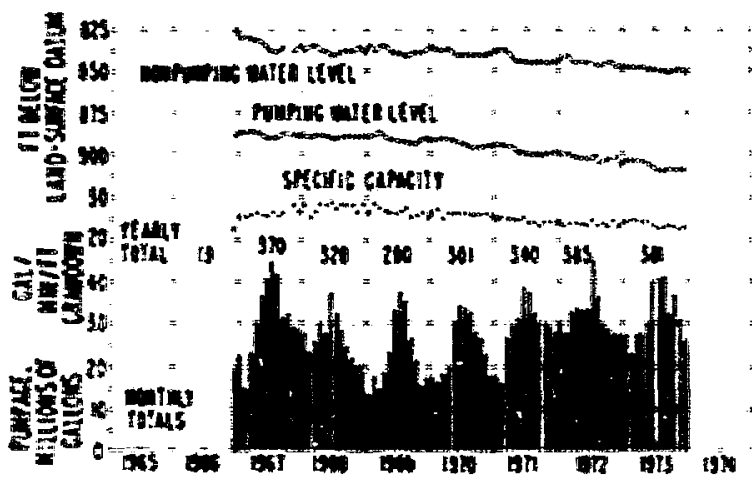

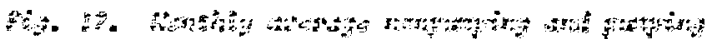
A

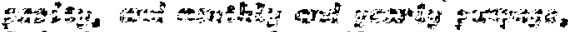

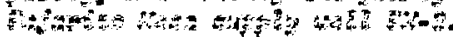

repaits and cleaning of sand frow the wells. Routine wantenance and repair of equifment during late fall, wincer, and carly spring wil best arepare equiputh for the heavi pamping season in lace spolnt and sumer when maxemo production is necessary.

The averase annwal pumplag race from the three fields decreased slighty; however, wase of the decrease occurred it wells that are being miled for repairs or replacenent. The specific capacieies of vells

TABLE I

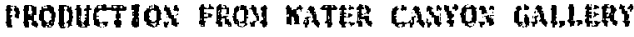
It stititoss of GaLtons

\begin{tabular}{|c|c|c|c|}
\hline 3oneh & 1971 & 192 & 2183 \\
\hline January & 3.2 & 3.3 & 4.3 \\
\hline Pebruary & 3.0 & 2.6 & 2.8 \\
\hline Nareh & 3.7 & 2.7 & 1.9 \\
\hline Apri1 & 3.6 & 4.1 & .9 \\
\hline Mat & 3.3 & 3.7 & 4.6 \\
\hline Sunc & 3.4 & 3.1 & 8.9 \\
\hline Suly & 2.8 & 3.1 & 8.0 \\
\hline Austest & 3.1 & 3.1 & 5.2 \\
\hline Soptcaber & 2.8 & 3.2 & 3.4 \\
\hline de cober & 2.6 & 3.5 & 5.8 \\
\hline Soverber & 2.5 & 1.0 & 2.5 \\
\hline Deecuber & 2.7 & 3.2 & 3.1 \\
\hline Toral & 36.7 & 59.6 & 49.2 \\
\hline
\end{tabular}


TABLE VII

WELt. ELEL PROUUCTION FOR 1967-1973

\begin{tabular}{ccc} 
year & \multicolumn{2}{c}{ Punpage } \\
\hline 1962 & MIIIOn Callons & $\frac{\text { Acre-Ft }}{1319}$ \\
1968 & 1402 & 4048 \\
1969 & 1335 & 4302 \\
1970 & 1337 & 4097 \\
1551 & 1553 & 4226 \\
1972 & 1510 & 4766 \\
1983 & 1566 & 4634
\end{tabular}

in the three fields vere within accoptable limies and were considered normal.

\section{v. RCONGENDATIONS}

New kells are considered cssential for continued efficient operation of the witer. supply system. Previous recommendations 2,3 for a new well in the pajarito well field and a replacemenz for well $6-4$ in the Guaje well field are still valid. Gordon llerkenhoff and Associates, Inc., ofter an engineering study, concur in these recomendacions, and, in fact, recommend three new wells in the pajarito field to satisfy the long-range rectuiremenes of the Los Mamos development. Their report is being prepared tor the USAEC and LASL. Action should be taken in the very near future to satisfy the need for the new wells to cover any shortage that may occur duc to the increasIng deand for pumpage duc to expansion of the laboratory and housing in the county. The $t$ ine necessary for completion of a well from design to production ranges from 18-24 months. An exceedingly dry spring and summer or outage of a high-yield well during the late spring or summer would probably result in a shortage of water for an indefinite period of tine without this additional capacity.

We again recommend that the annual pumpage be 1 imited to no more than $400 \mathrm{mil}$ $I$ ion gal from the Los Alamos field and no more than 500 milion gal from the Guaje field, with addicional required water to be pumped from the Pajarito field. Since 1967, when these restrictions were first established, there has been either a reversal or deceleration of water-level declines in most of the wells in the Los Alamos and Guaje fields.

\section{REFERENCES}

1. W. D. Purtymun and J. E. Herceg, "Summary of Los Alamos Municipal Weil Field Characteristics, 1947-1971," Los Alamos Scientific Laboratory report LA-5040-MS (1972).

2. H. D. Purtymun and J. E. Herceg, "Water Surpiy at Los Alamos During 1971," Los Mlamos Scientific Laboratory report LA5039-MS (1972).

3. W. D. Purtymun and J. E. Herceg, "Water Supply at Los Alamos During 1972," LoS Alamos Scientific Laboratory report LA-5296-MS (1973).

4. "Comprehensive Plan for Water System Improvements, Los Alamos, New Mexico," Gordon Herkenhoff and Associates, Inc., Engineers anc Planners, 302 Eighth St., Albuquerque, New Mexico, 87102, Contract Number AT (29-1)-2201 (1974). 


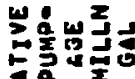

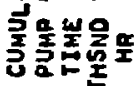

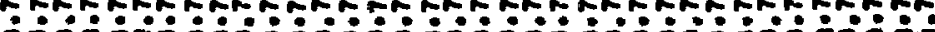
คำ

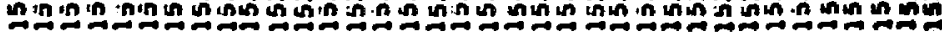

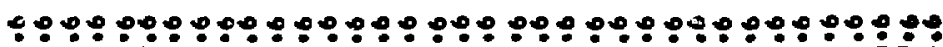
OO00000000000000000000000000000

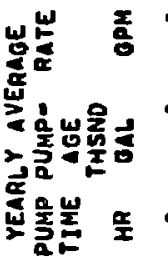
000000000000000000000000000000000000 000000000000000000000000000000000000 000000000000000000000000000000000000

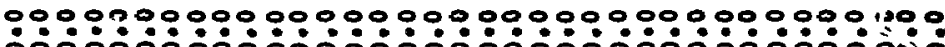

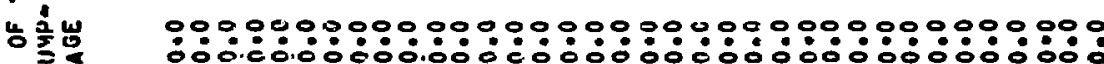
U:

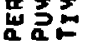

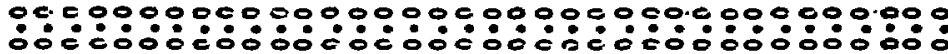

000000000000000000000000000000000000 -000000000000000000000000000

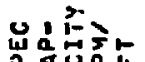
各过造造

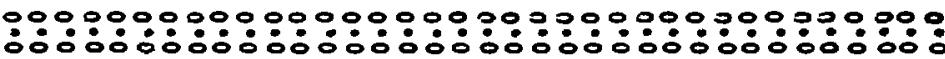
종종 능

000000000000000000000000000000000000 $\therefore 0000000000000000000000000$

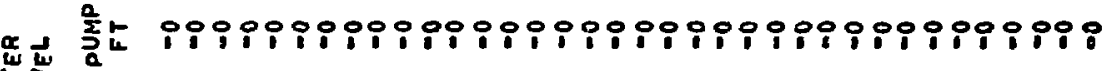

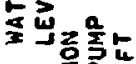

000000000000000000000000000000000000 . 远

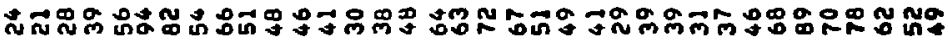

㟶旁

000000000000000000000000000000000000

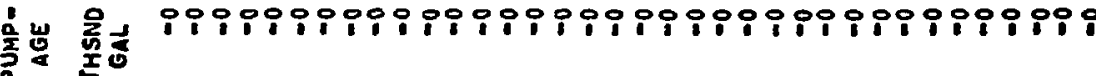

产崖 x ipipipipipipipipipipipipipipipipi

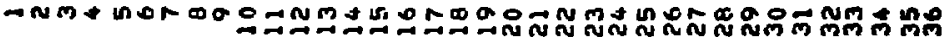

$\stackrel{\omega}{a}$

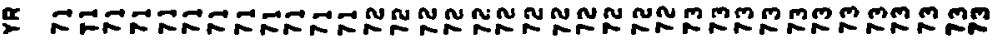

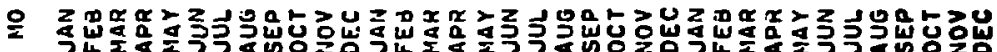




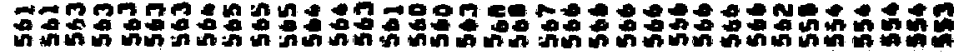

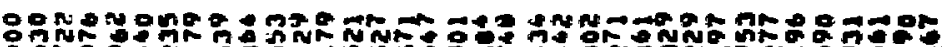
800

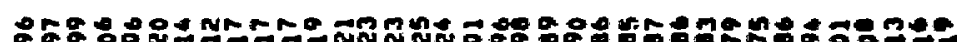

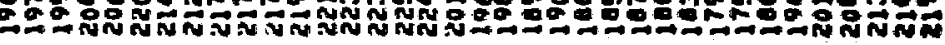

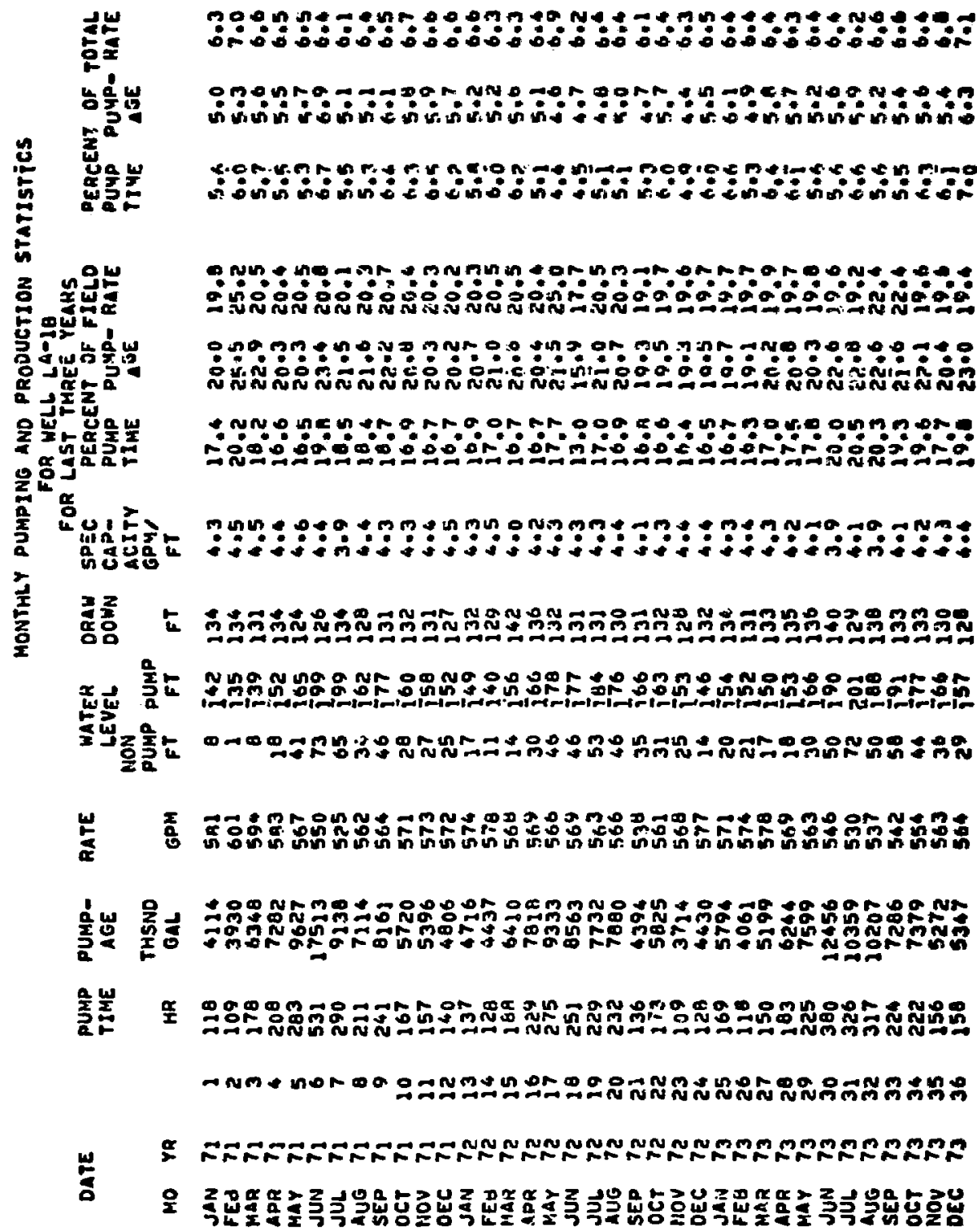




\section{4 บ

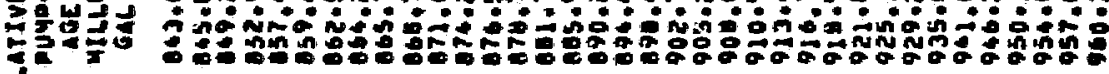

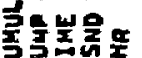

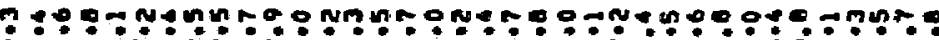

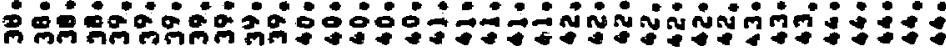

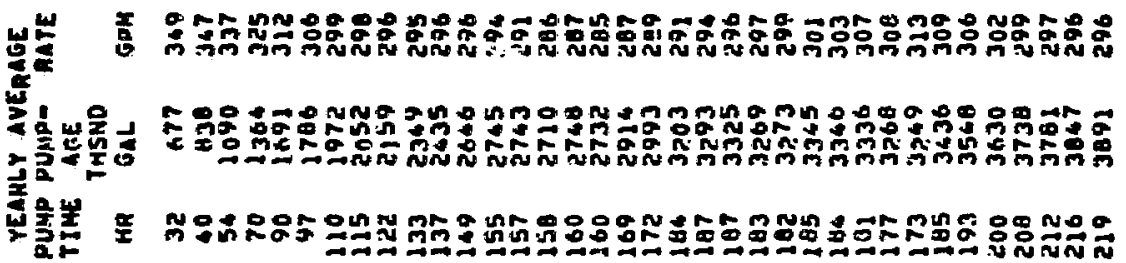

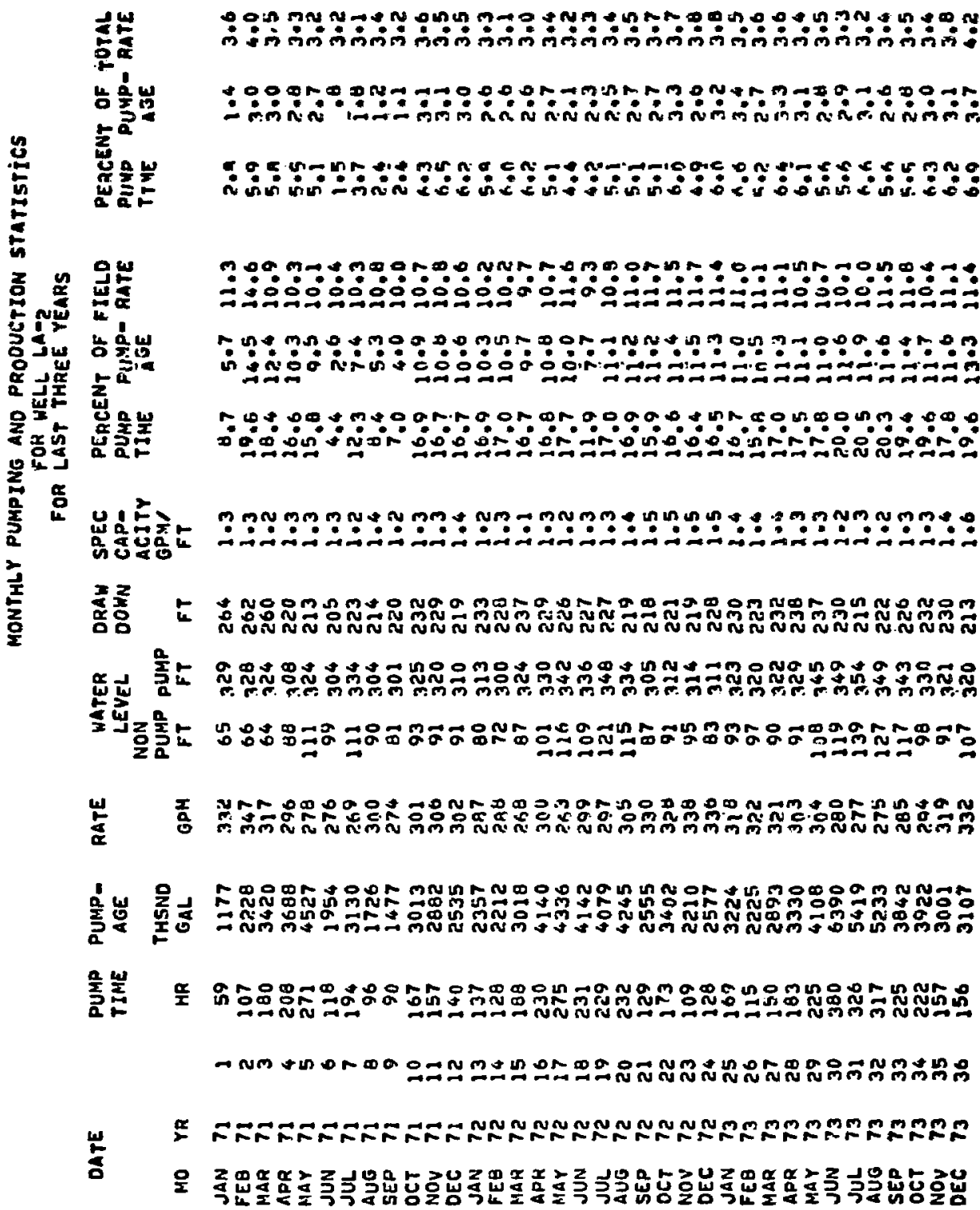




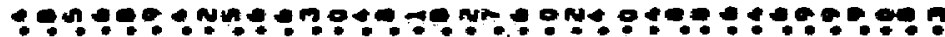
பं 24R

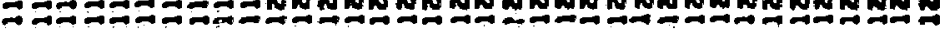

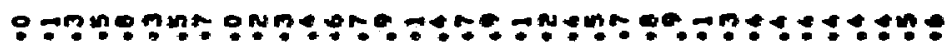

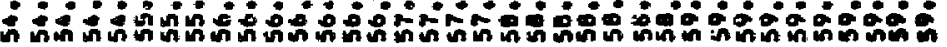

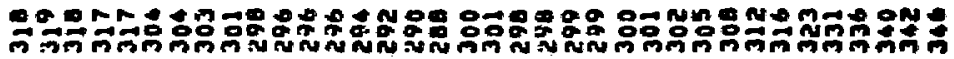

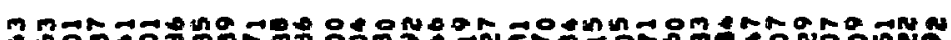

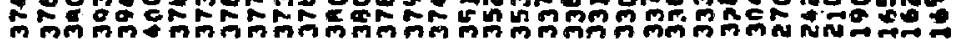

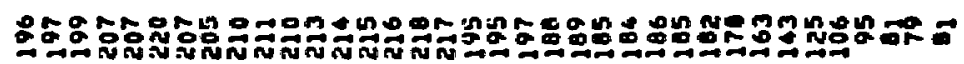

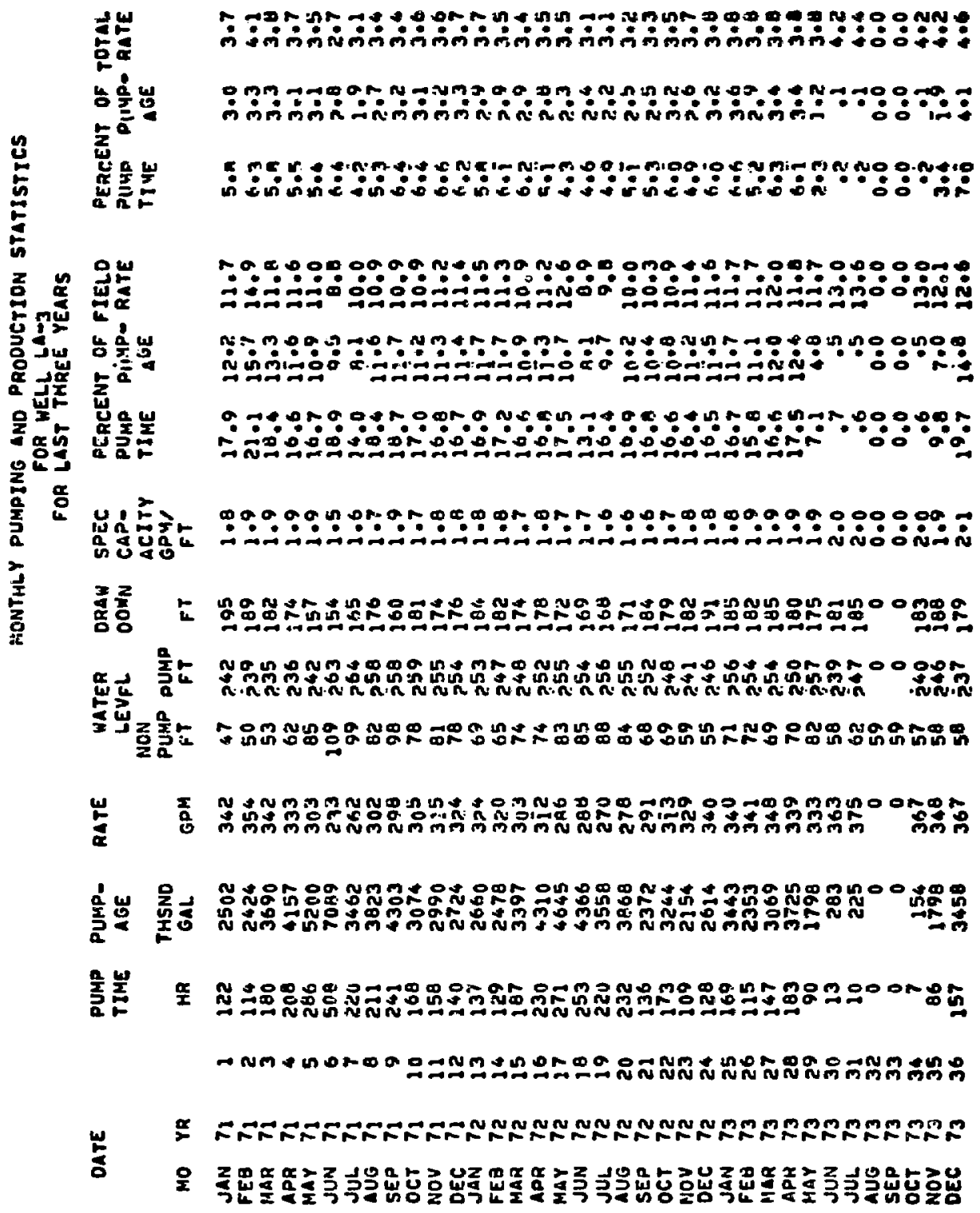




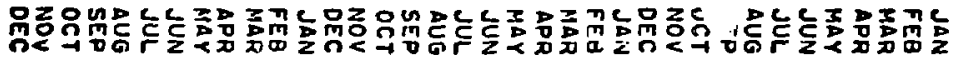
๘๐ผ

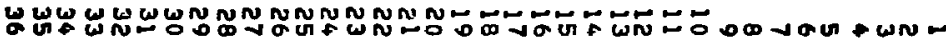

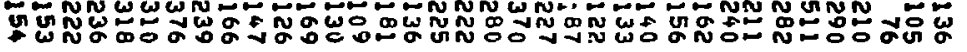

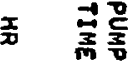

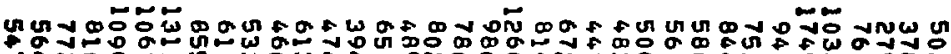

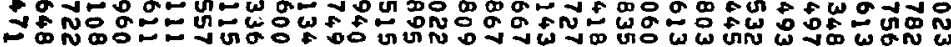

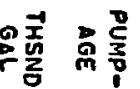

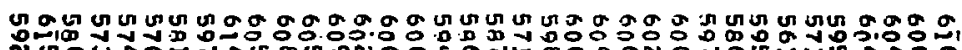

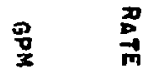

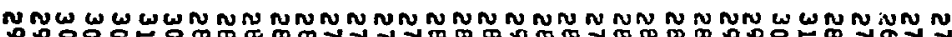

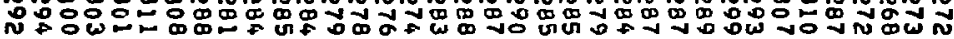

*

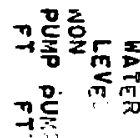

م

I. 学员

jo

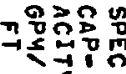

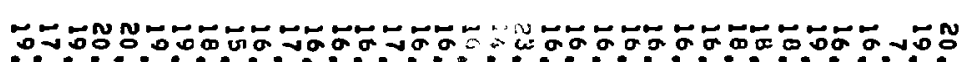

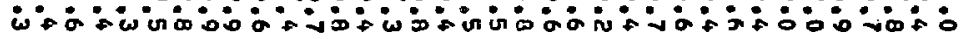

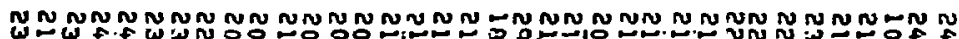

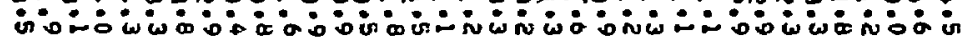

\&NO

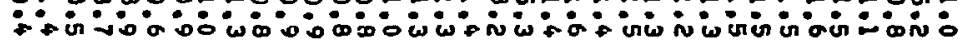

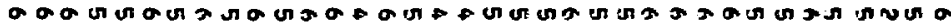

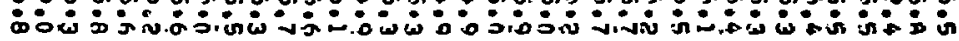

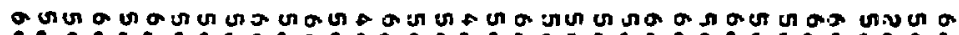

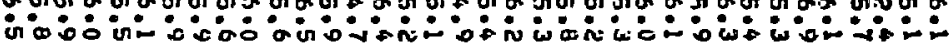

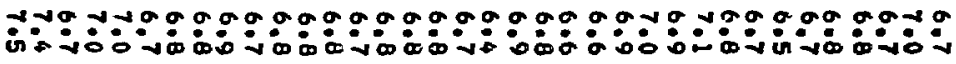

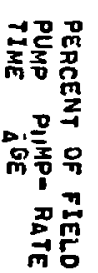

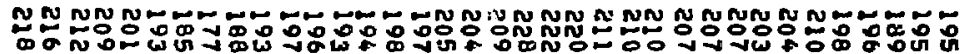

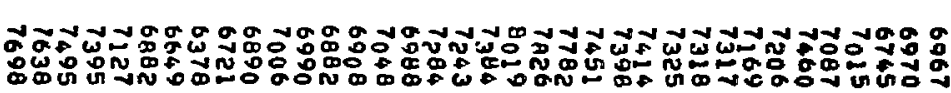

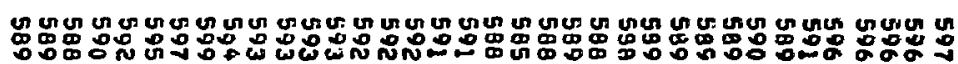




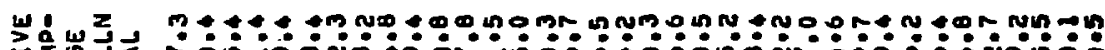

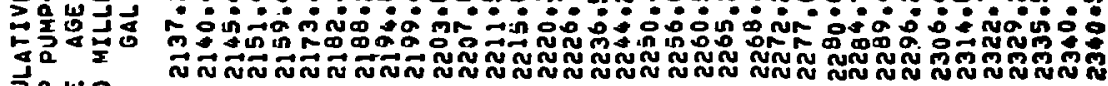

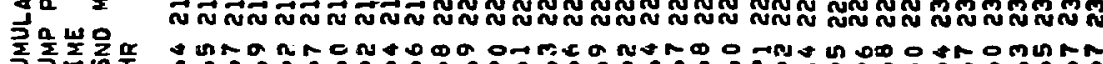

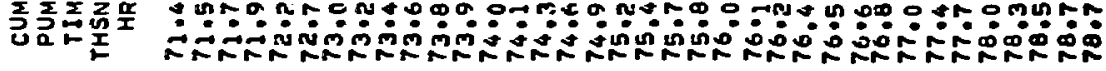

岁点

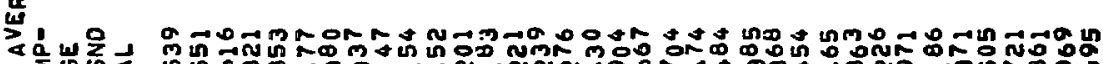

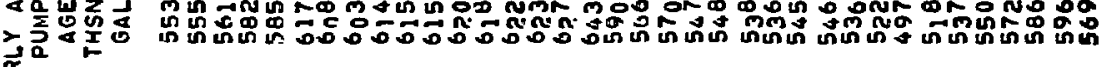

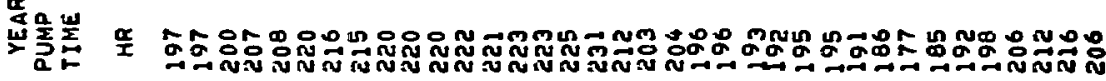

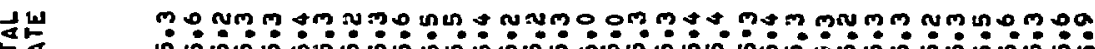

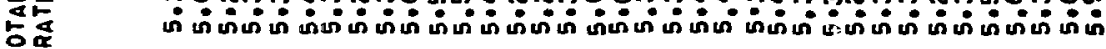

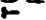

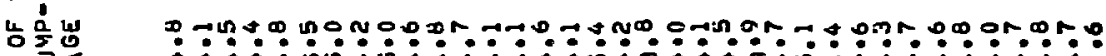

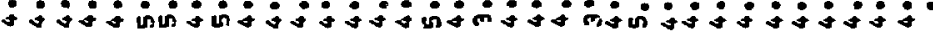
$\frac{1}{2}$ $\sum^{2}$

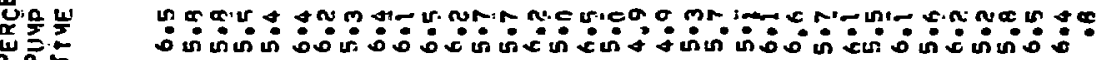

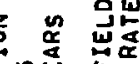

5 in

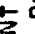
is

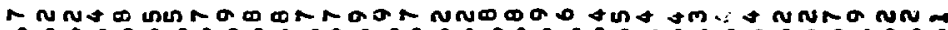

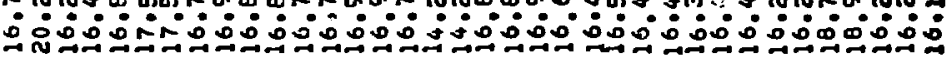

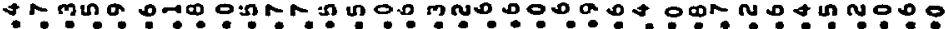
ód 0 a

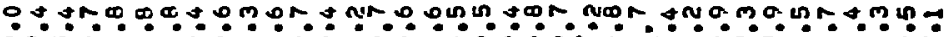

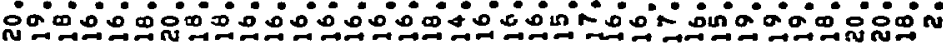

U. की

중 ดी

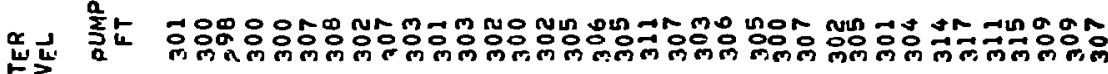

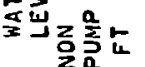

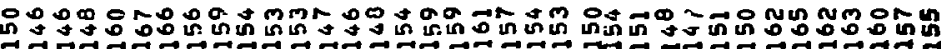

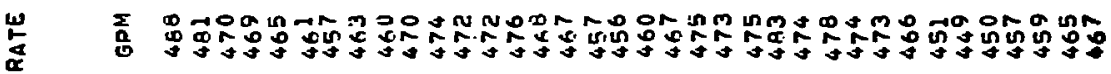

a

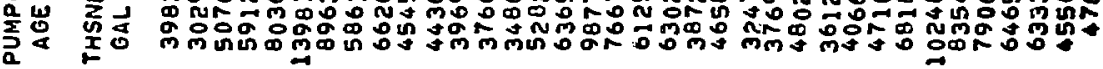

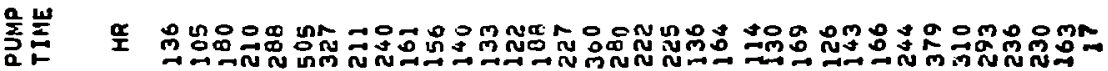

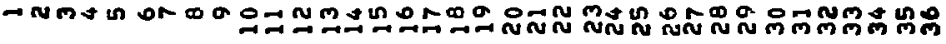

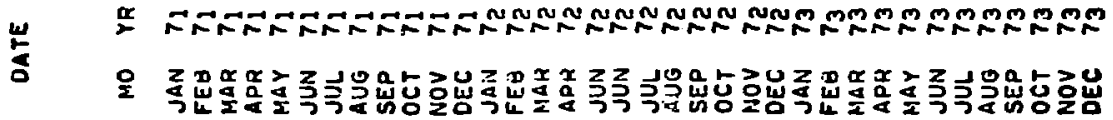




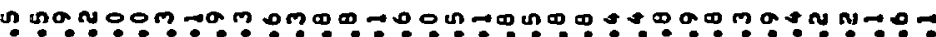
- maำ

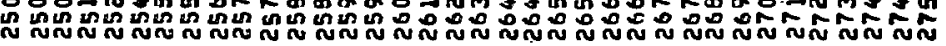

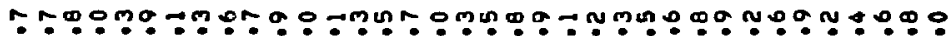

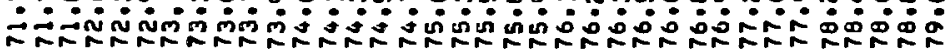

岁岁

풍

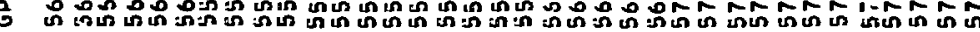

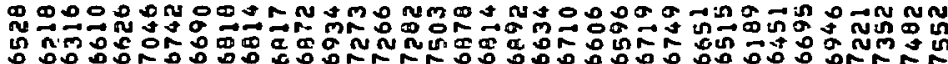

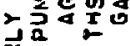
嵌带崖

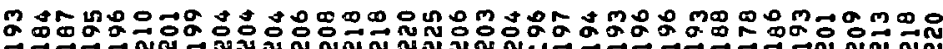

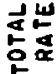

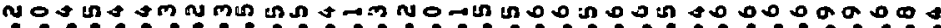

它空岁 : คำ. $\sum^{2}$ 这呈步

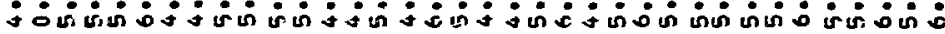

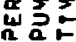

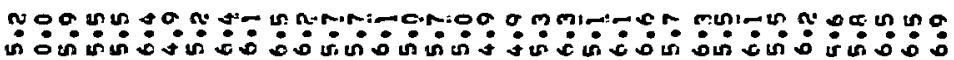

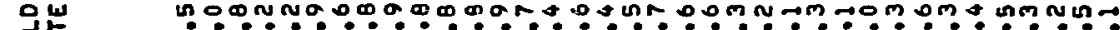

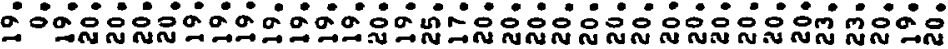
ถั่ $5 \mathbf{a}$ บ0 7

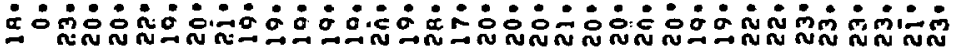
il

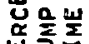

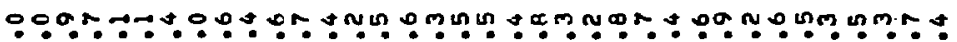

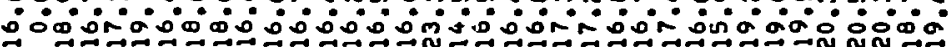

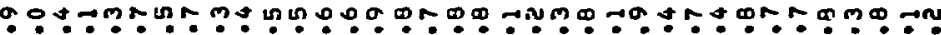

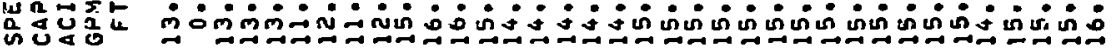

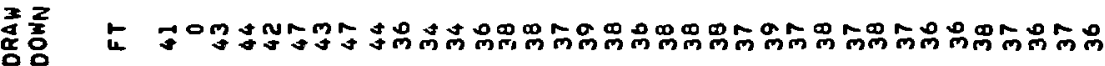
산

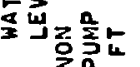

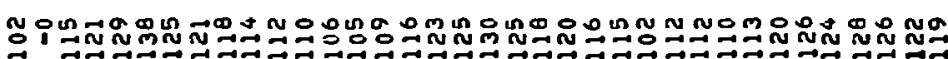

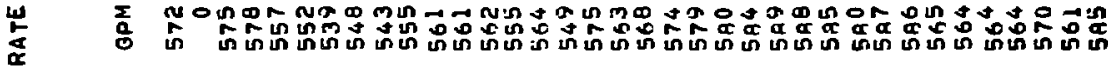

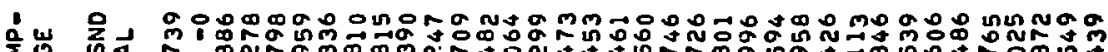

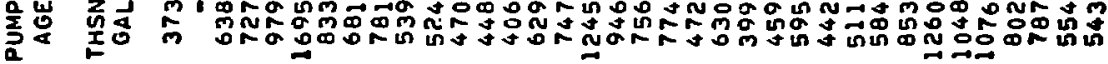

高崖

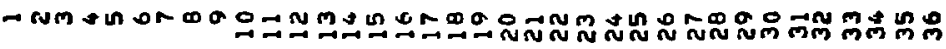

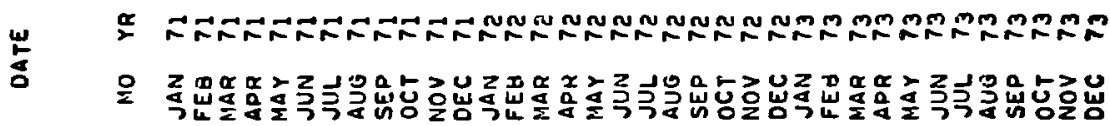




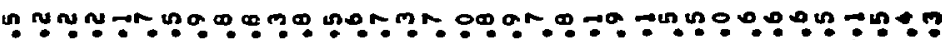
:

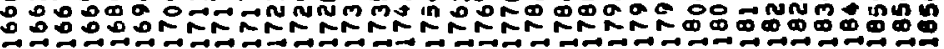

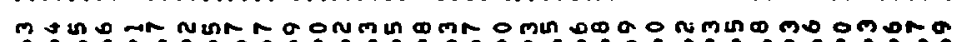

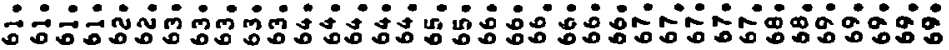

แ山

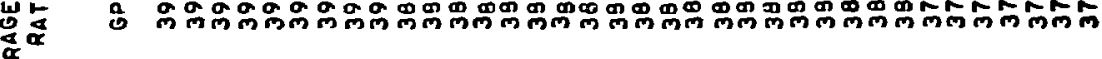

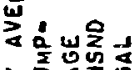

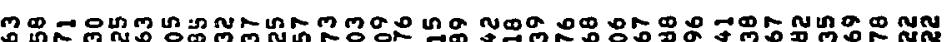

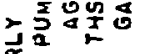

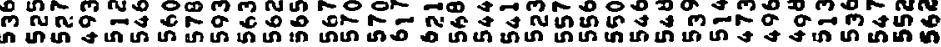

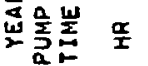

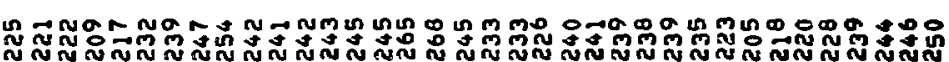

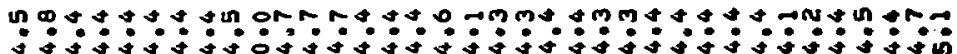

L는 m

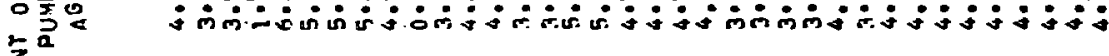
zis

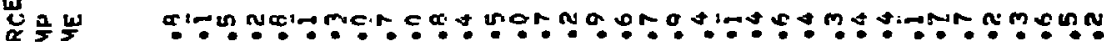
a

\section{O

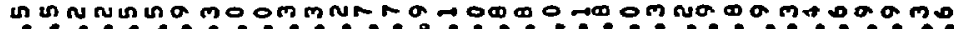 :

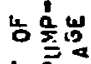 $\sum_{\text {tut }}^{5}$

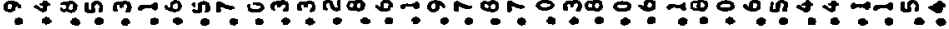

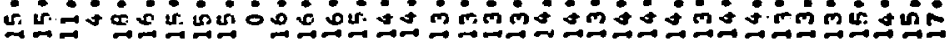

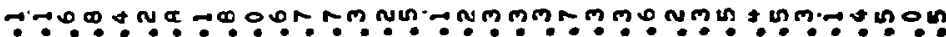 $000 \div 0000000004 \pm 040$

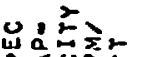 \\ O

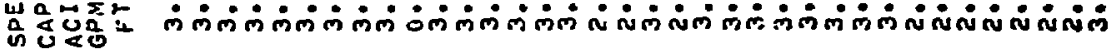 \\ 蛋录 ᄂ

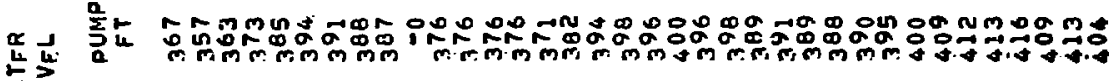

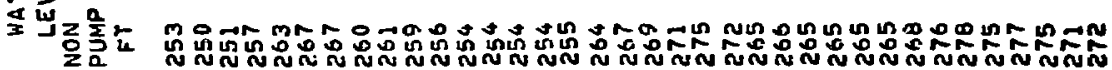

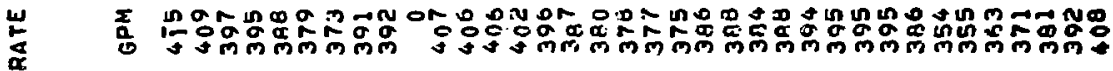

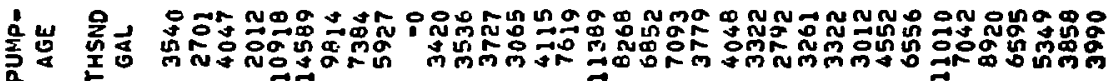

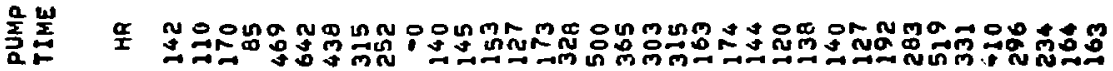

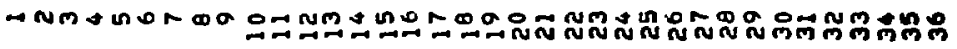

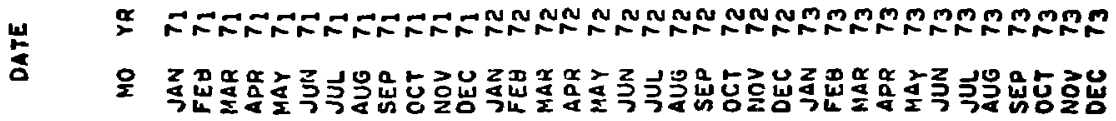




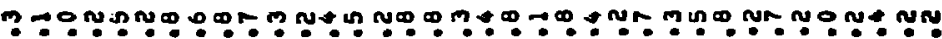

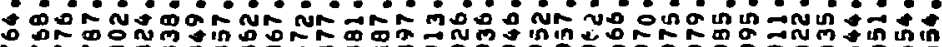

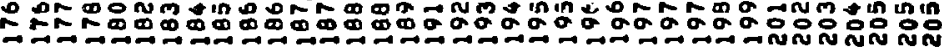

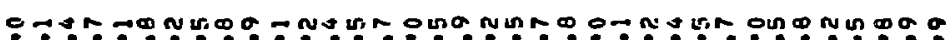

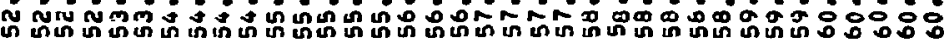

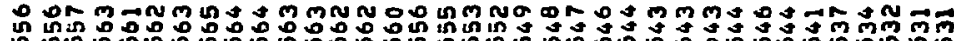

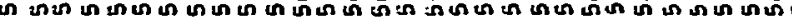

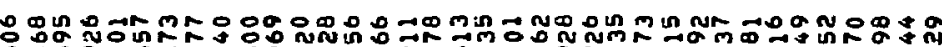

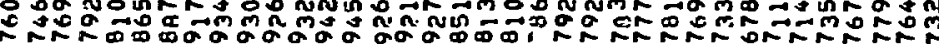

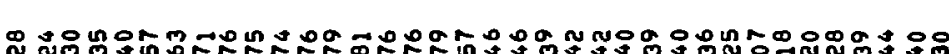

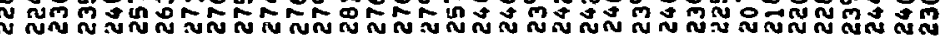

造崖

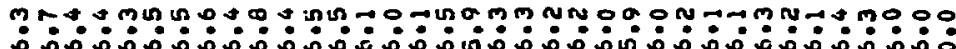

농ํㅜㄴ $5 \mathrm{~S}^{5}$

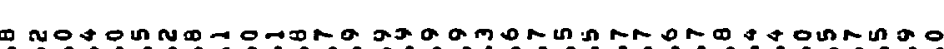

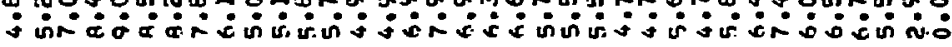

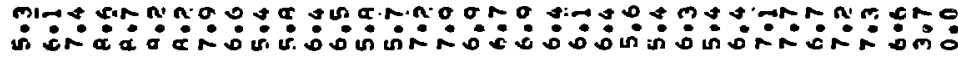

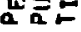

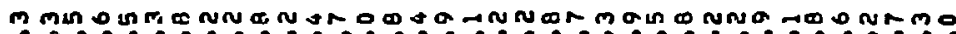

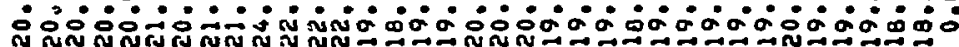

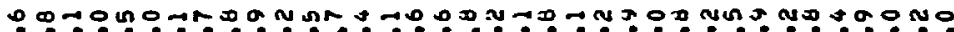

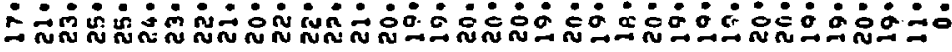

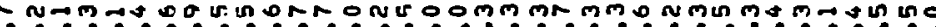
ก

ง nนmน

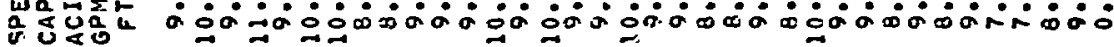

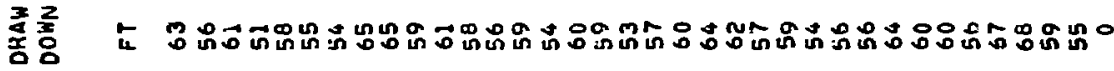

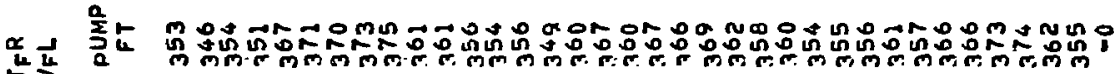

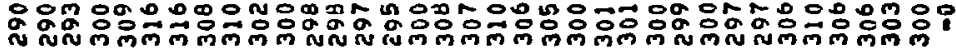

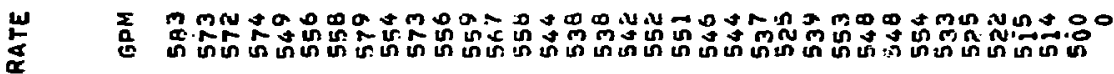

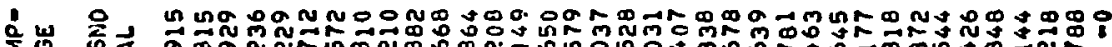

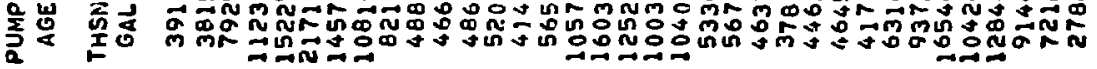

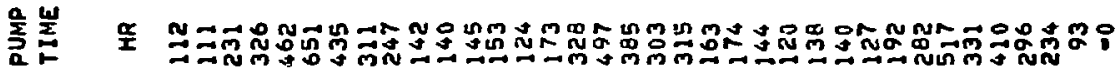

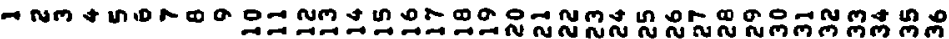

$\frac{\omega}{0}$

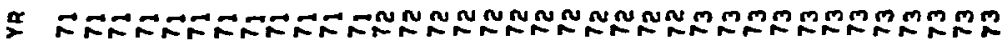

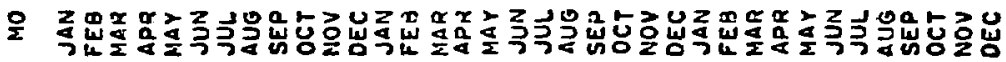




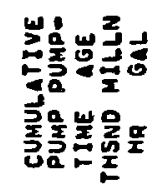

․ no: : : ging

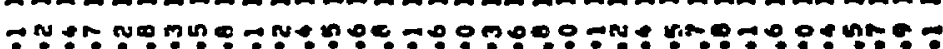
ดे

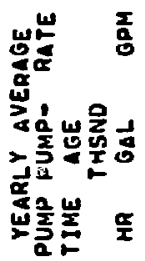

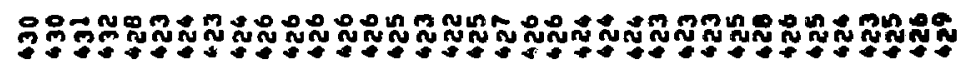

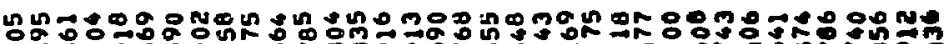
ถ้ำ

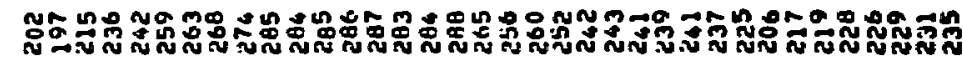

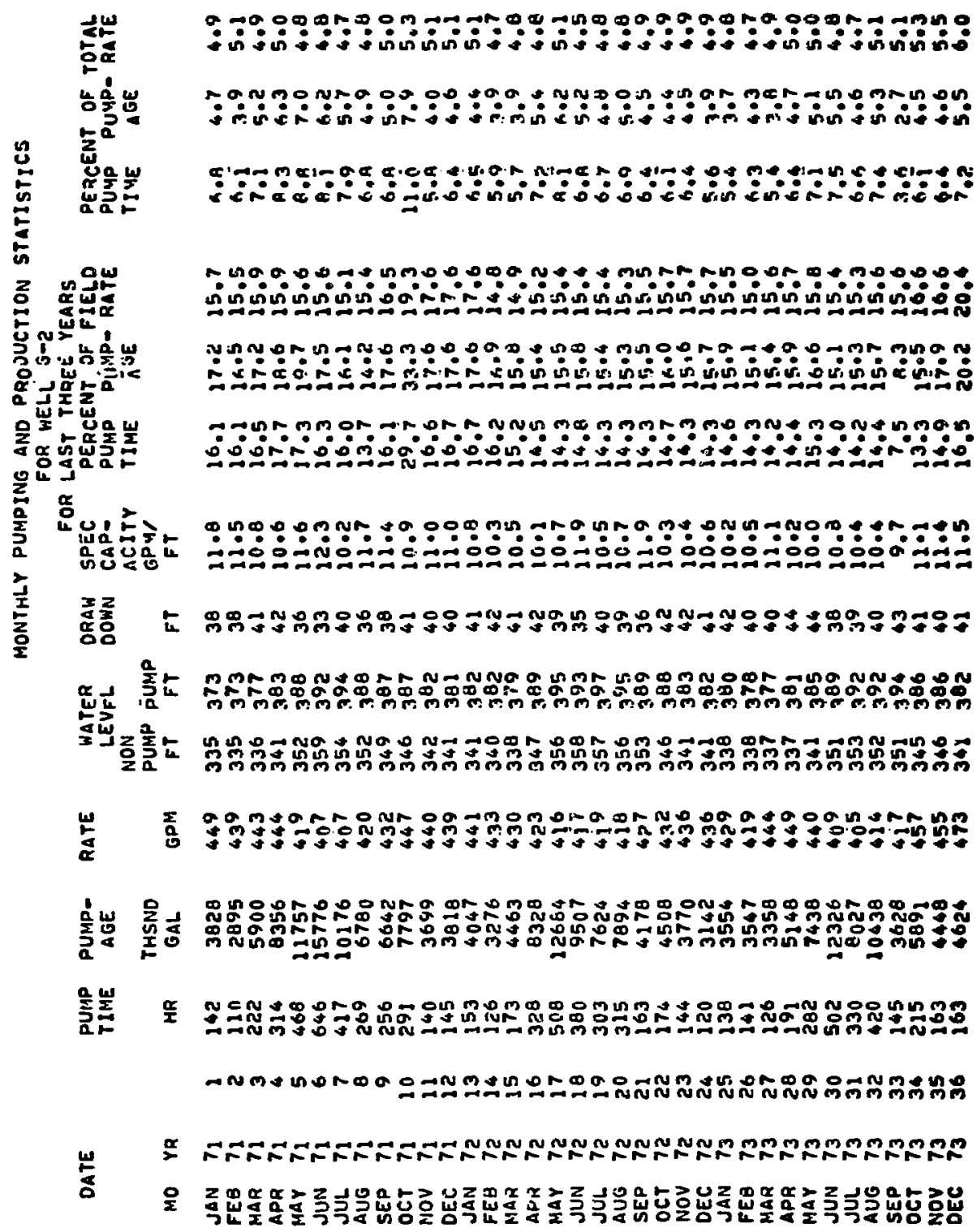



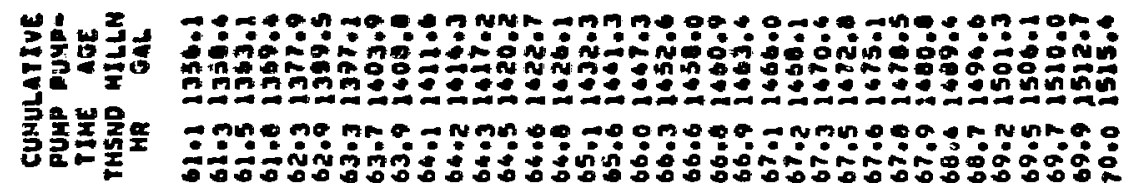

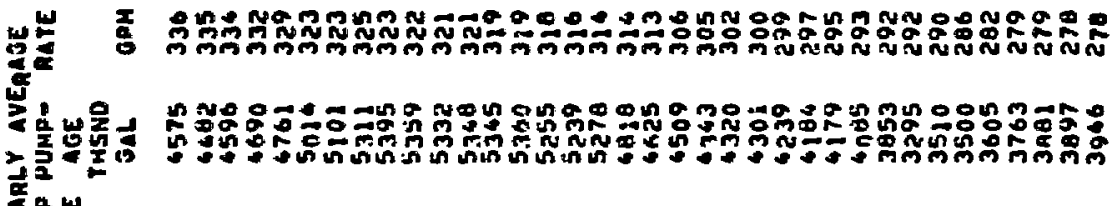

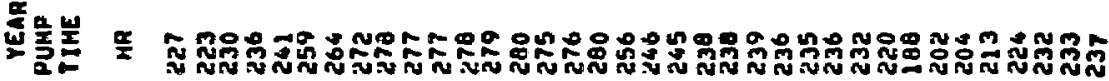

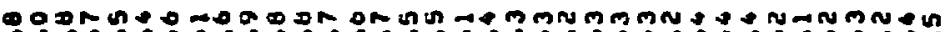

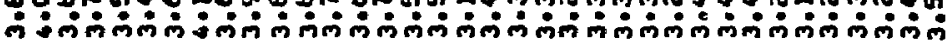

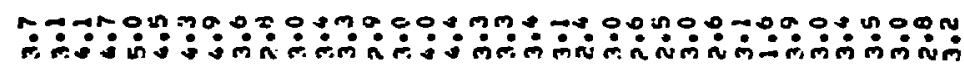

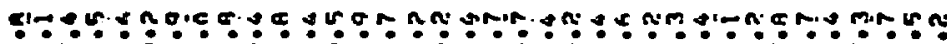
ine

본 $\quad$ 분 $\pi$ 苍旁岂 5 บ บN

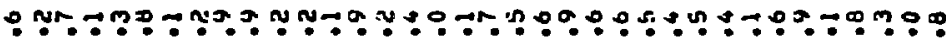

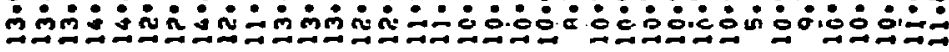

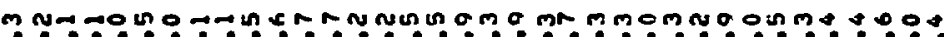

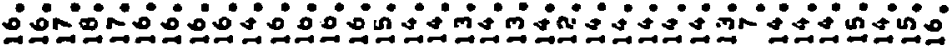

\section{ui: 2}

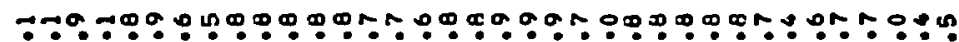
Q

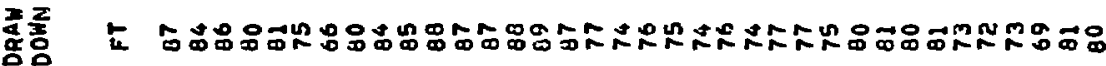

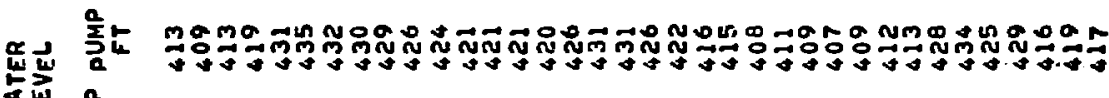
$\leq$ in

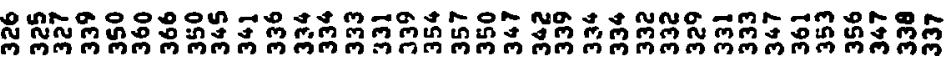

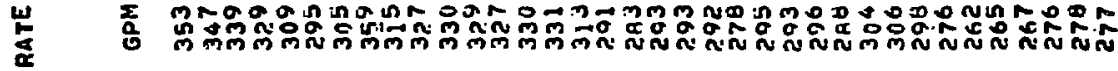

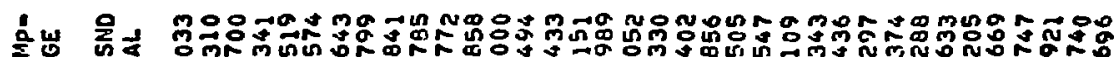

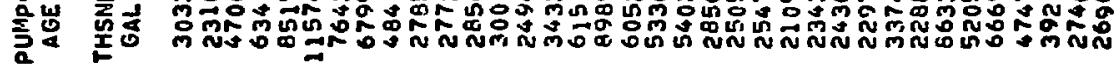

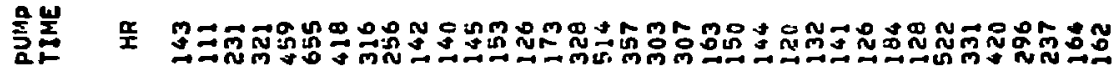

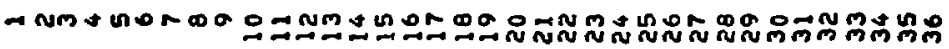

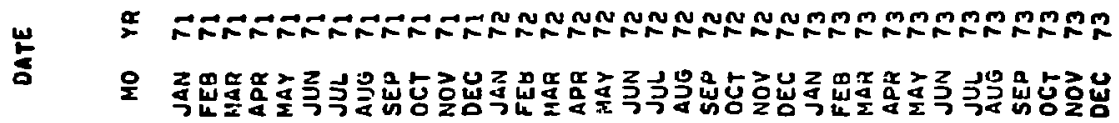




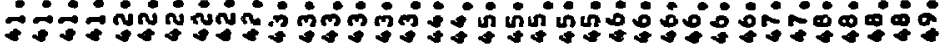

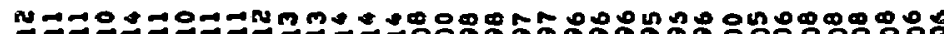

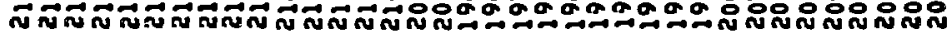

공ำ

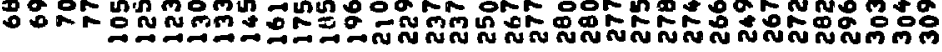

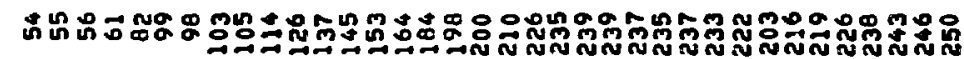

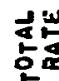

㟔亭岁

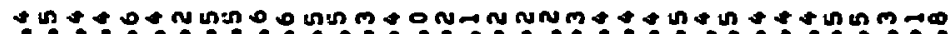
บ

$z_{\mathrm{w}}$ $\because$ *:-

这资高

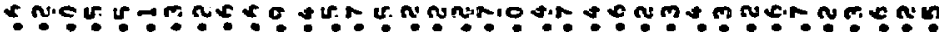

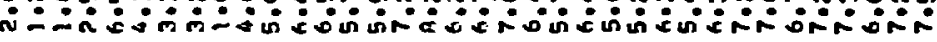

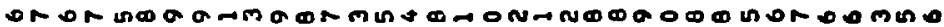

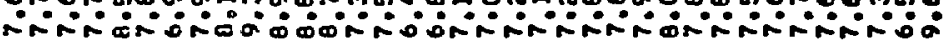

N ONRO M

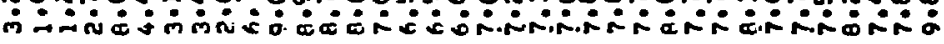

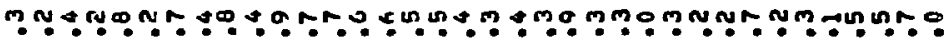
- min no

U:

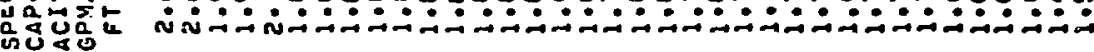

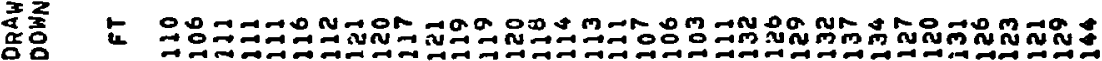

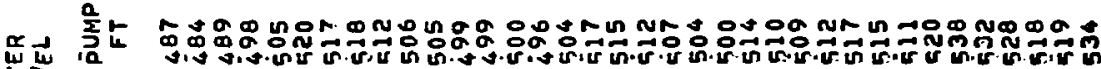

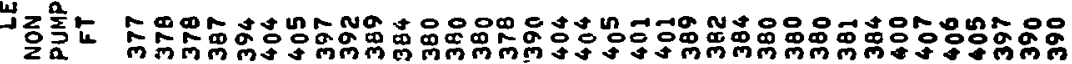

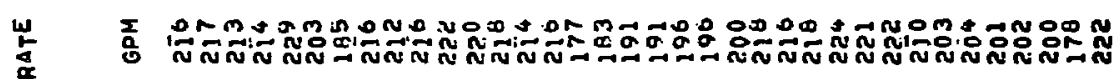

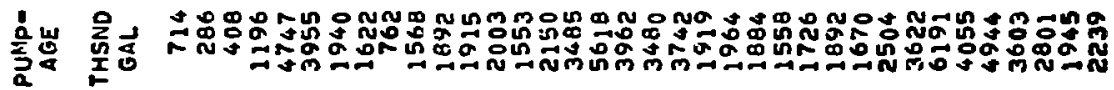

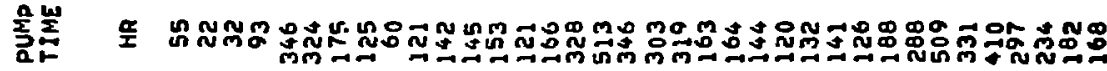

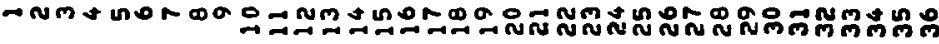

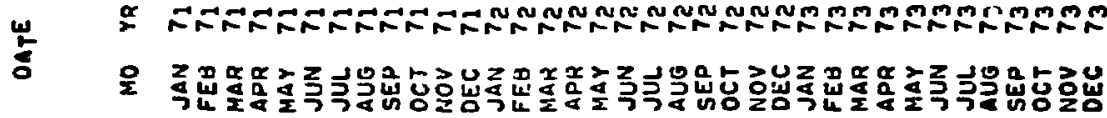




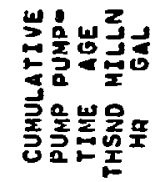

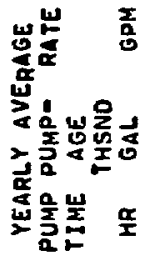

\section{西}

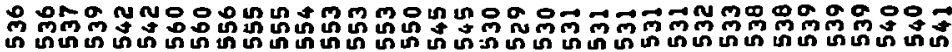

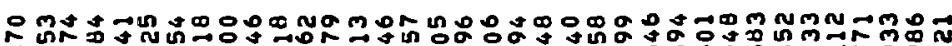
mingoson

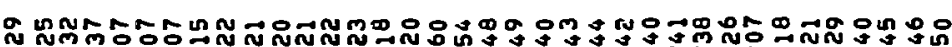

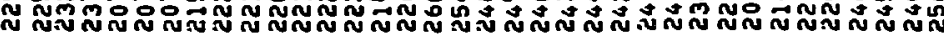

ํㅗㄴ

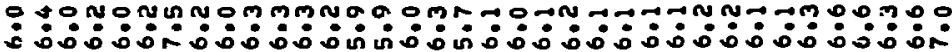

능올

号

占造

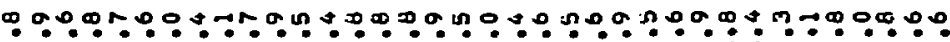
in jor in

ón

OL m m

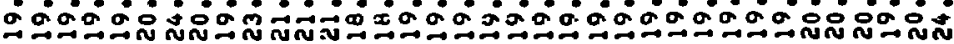

2

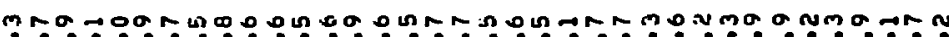
ง ? :0. 7004

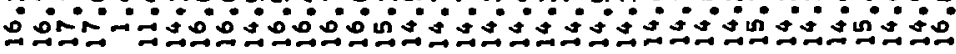

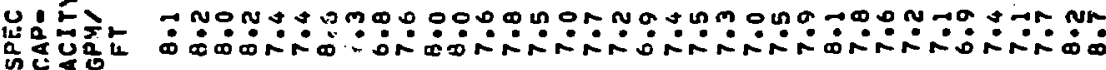

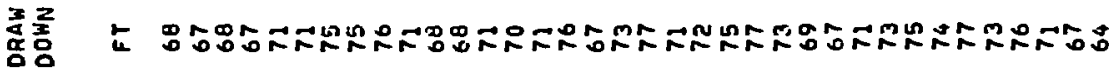

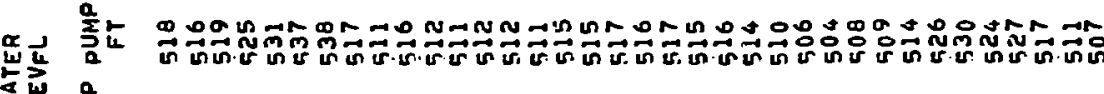

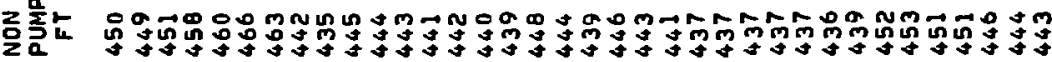

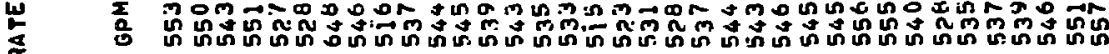

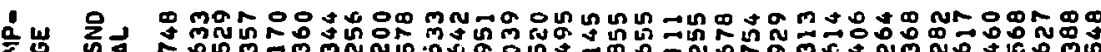

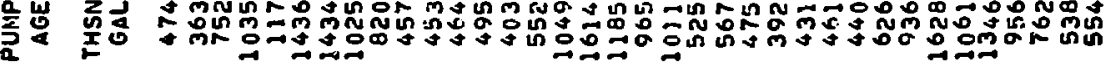

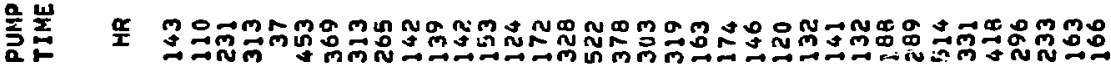

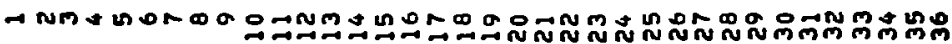

岁

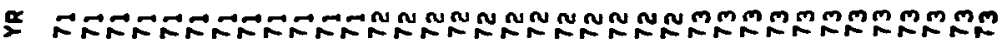

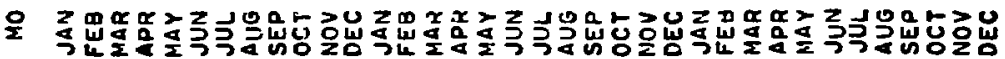




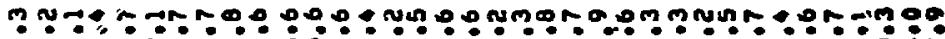
जिं0

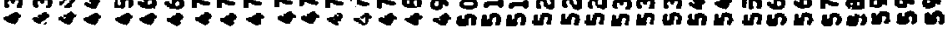

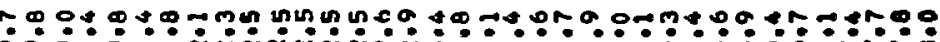

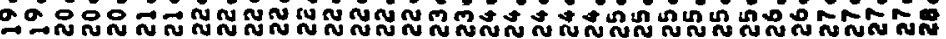

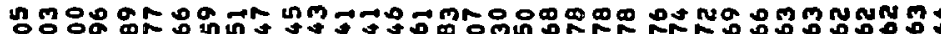

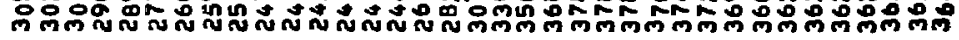

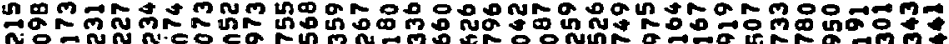

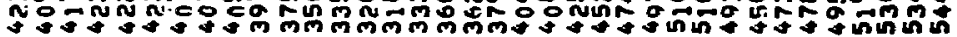

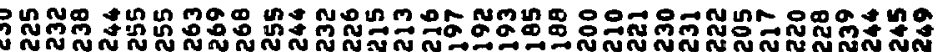

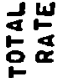

ᄂ

50

w

岀紧

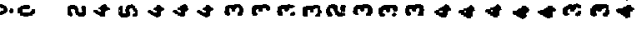

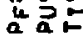

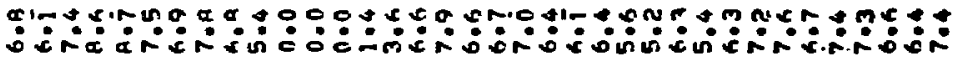

a

造

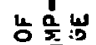

$上 \overline{\mathbf{a}}^{\circ}$

$\sum_{\text {tit }}$

这崖

a

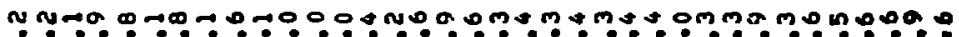

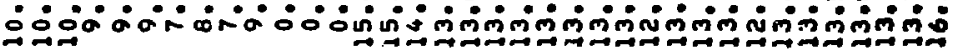

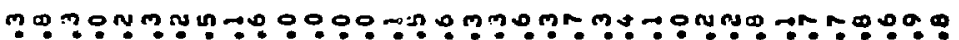

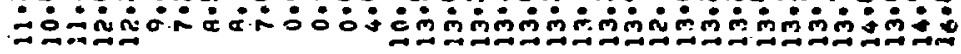

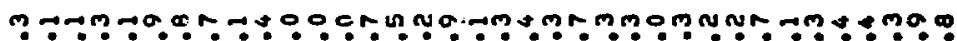

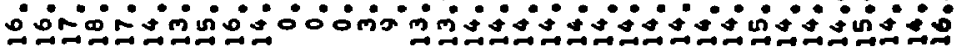

U는

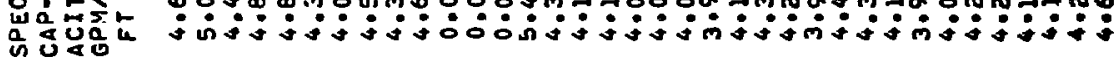

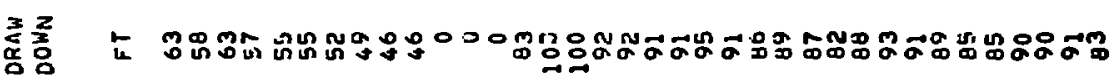

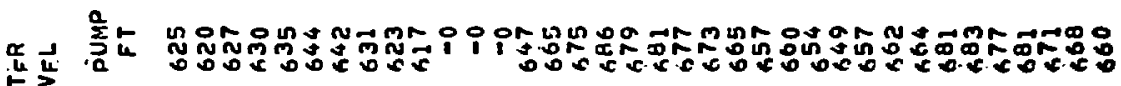

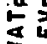

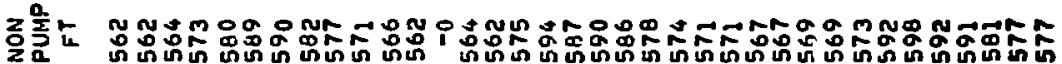

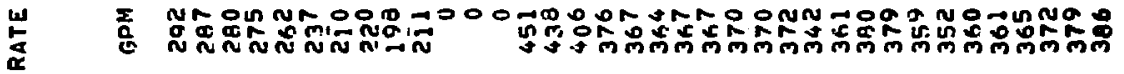

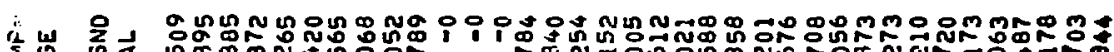

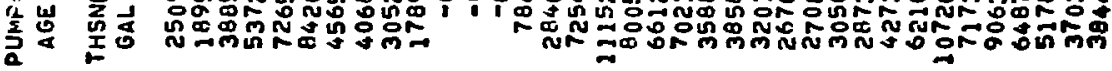

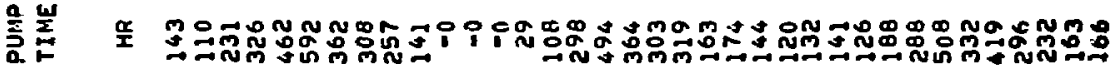

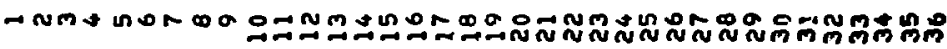

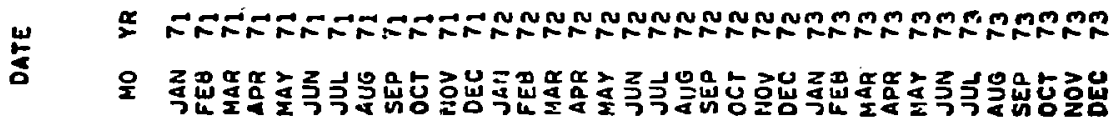




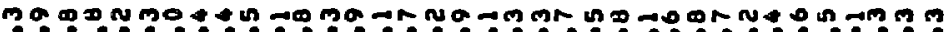

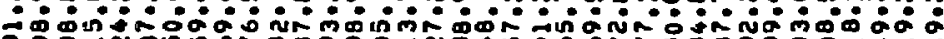

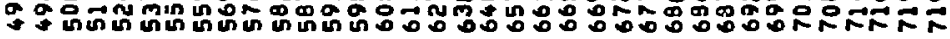

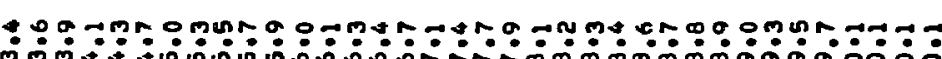

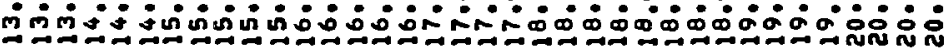

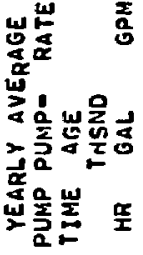

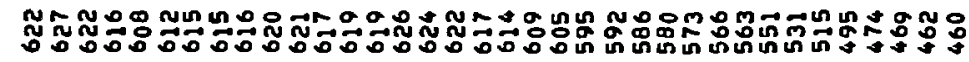

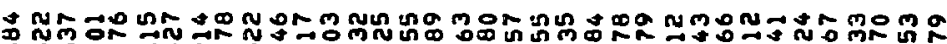

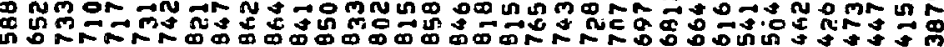

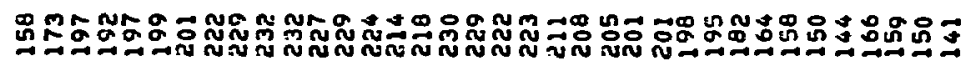

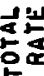

岁管岁



藏

wै

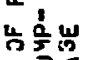
$5 \vec{a}^{2}$ 这量

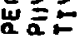

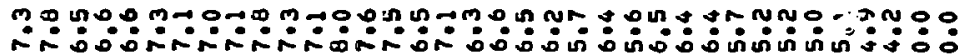
หง

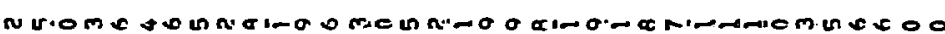
n. 岁鱼崖

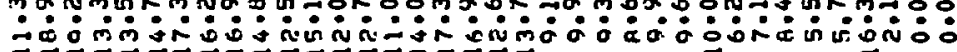

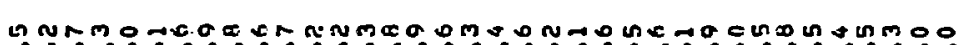
ำ U⿺辶一

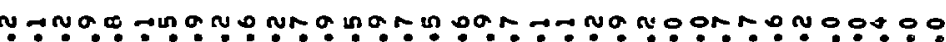

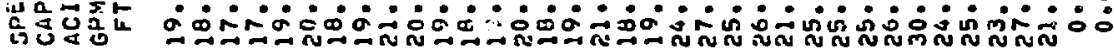

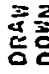

$\frac{0}{2}$ 高上

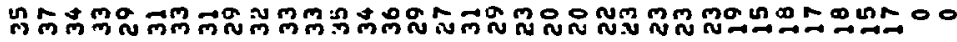
is

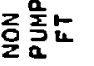

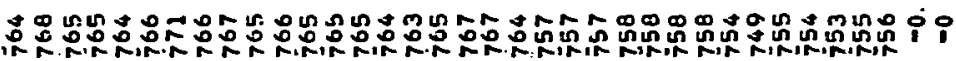

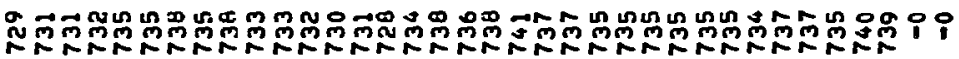

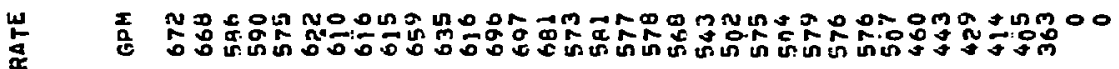

는 응

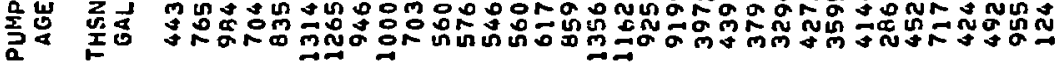

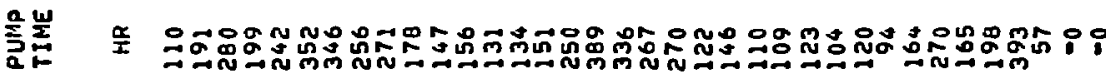

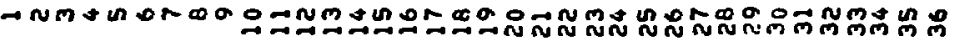

$\stackrel{\omega}{\underline{a}}$

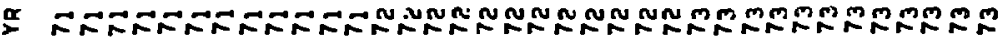

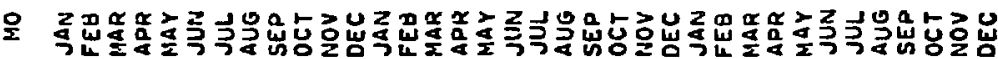




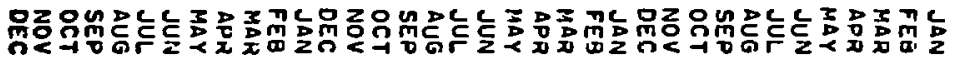

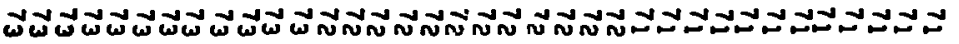

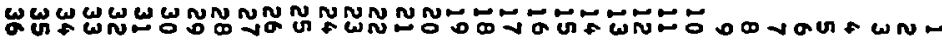

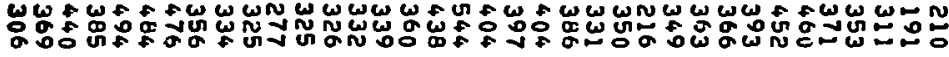

핌 索突

NWWW

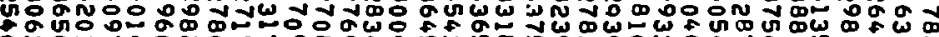

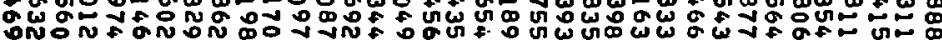

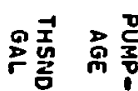

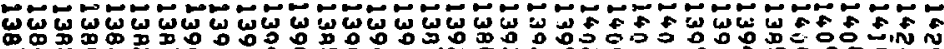

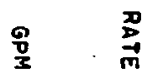

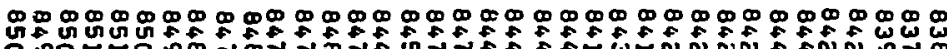

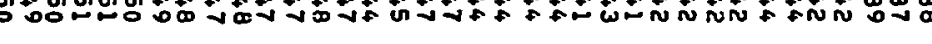

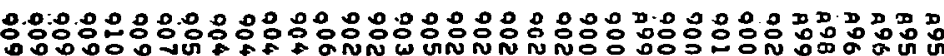

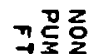

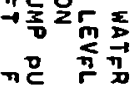

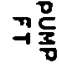

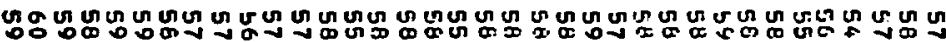
ᄁᄁ

율욜

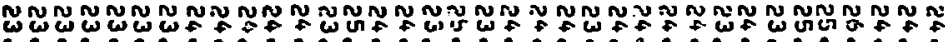

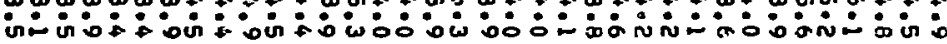

고요용

$\rightarrow \leq \frac{1}{2}$

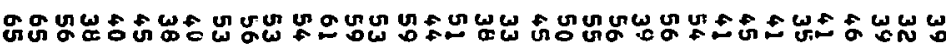
- wivo in

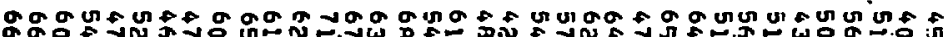

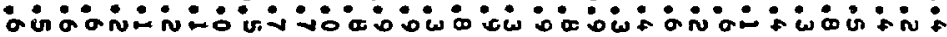

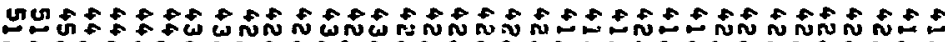
Zwa

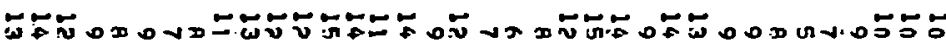

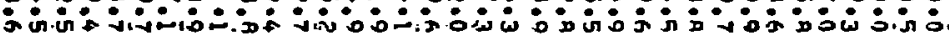

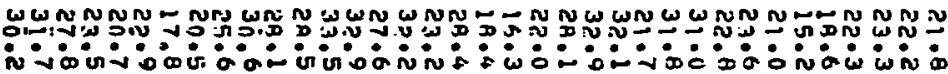

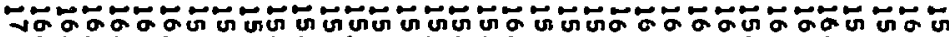
is

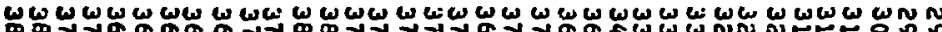

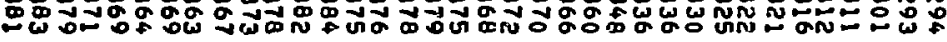

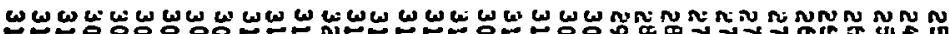

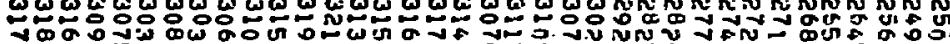
w

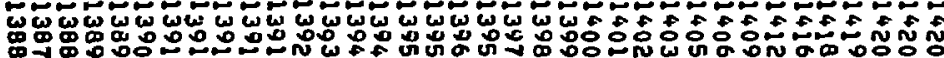

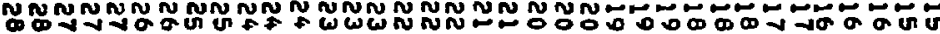
in

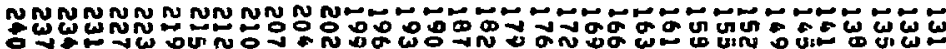

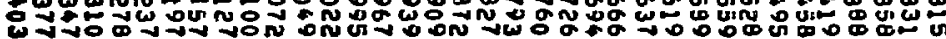
E: 


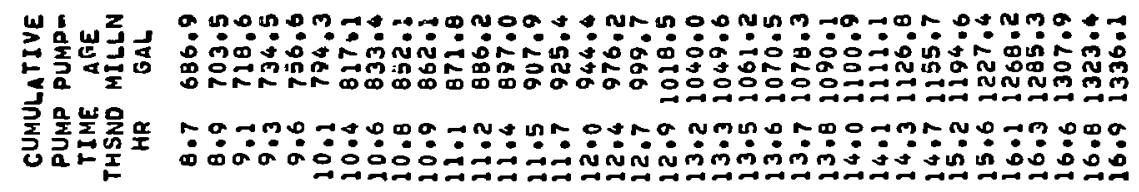

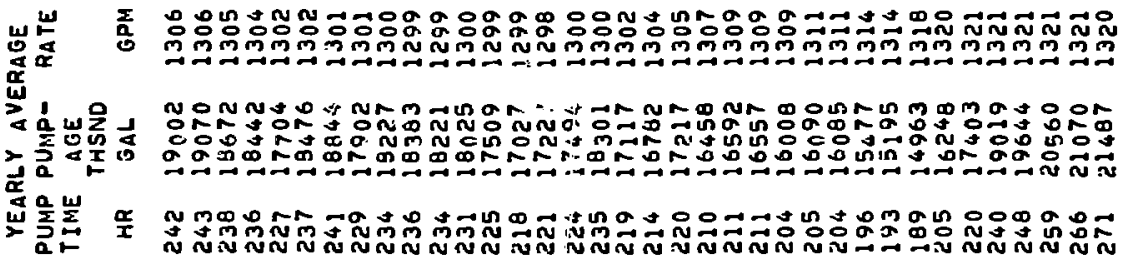

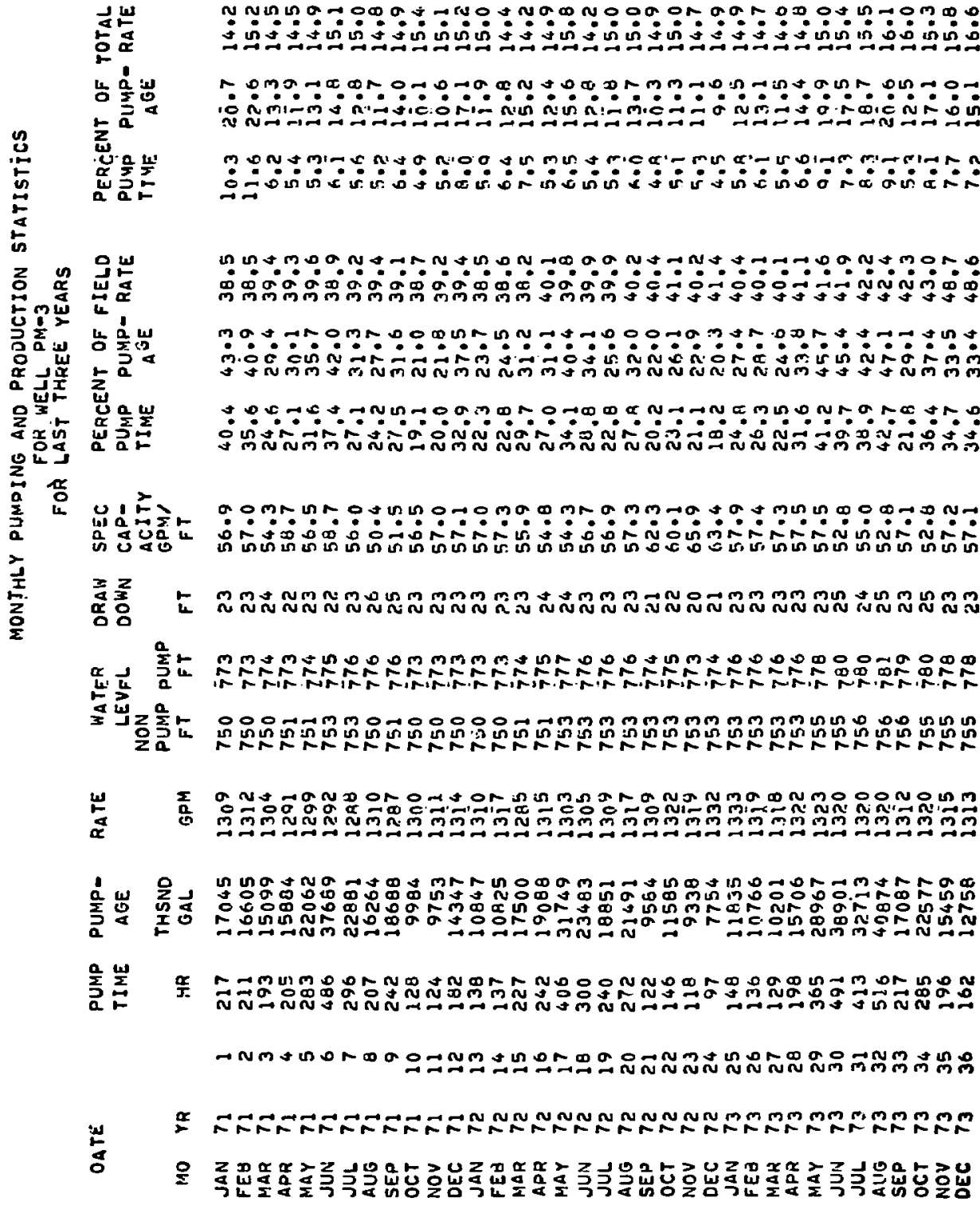

